\title{
Education and literacy in ancient Italy: Evidence from the dedications to the goddess Reitia*
}

\author{
KATHERINE MCDONALD
}

\begin{abstract}
This article discusses the votive dedications to the goddess Reitia at the sanctuary of EsteBaratella (Veneto) as evidence for the acquisition of literacy in Italy c. 350-150 B.C. These dedications, which take the form of bronze writing tablets and styluses, are inscribed with Venetic dedicatory formulae, abecedaria and other writing exercises. This article shows how these texts function as writing exercises - some of the earliest evidence of elementary education methods in Italy. Many of the votives were dedicated by women, and this article argues that women were active participants in literacy and education in this period. It also sets the dedications in their Italian and Mediterranean context by comparing them to votive and funerary deposits of abecedaria from across Italy and the ancient world.
\end{abstract}

Keywords: Venetic; Reitia; dedications; votives; literacy; education; women

\author{
I INTRODUCTION
}

\footnotetext{
*Earlier versions of this paper were presented to research seminars at the Universities of Cambridge, Exeter and Newcastle in 2016 and 2017, at the conference 'Parole per gli dèi' at the Academia Belgica in May 2017, and at the British Epigraphy Society Autumn Colloquium in November 2018. I would like to thank these audiences for their comments and suggestions, particularly Daniele Maras and Philippa Steele. Patrick Clibbens, Philip Boyes, Emma-Jayne Graham, Liv Yarrow and Anna Judson also read the manuscript in its second and third incarnations and offered many helpful comments. Many thanks to the JRS readers, whose advice greatly improved this article and widened its scope. I would also like to thank the Museo Nazionale Atestino for permission to study and photograph the inscriptions discussed here. A large portion of this research was completed during a Rome Award at the British School at Rome in 2015, and I would like to thank the BSR for their generous support.
} 
There are limited sources to determine who learned to write in Italy in the centuries after writing was brought to the peninsula, and there is even less information on methods of education in this period. Most of the evidence on ancient elementary education practices comes from the Greek world, and particularly from Hellenistic and Roman Egypt. ${ }^{1}$ The handful of Roman Republican literary sources which refer to education are often understood to imply (a) that literacy was usually limited to elite boys; (b) that the early stages of education, such as learning the alphabet, were mainly undertaken in the home; and (c) that education only started to become more structured in Italy when Greek models were imported to Rome during the Late Republic. ${ }^{2}$ However, this picture is incomplete. Looking beyond Greek and Latin, the other languages of Italy provide valuable information about how writing was taught, who learned to write, and the possibility of schooling outside the home in Italy. ${ }^{3}$

This article examines the Venetic dedications to the goddess Reitia at the EsteBaratella sanctuary as evidence for elementary education in Italy in the fourth to second centuries B.C. These texts appear on dedicatory bronze writing implements - specifically, writing tablets and styluses - inscribed with imitations of learners' exercises (or teachers' models) such as abecedaria, lists of consonants and groups of consonant clusters. Some of these texts seem to state that the abecedaria, rather than the bronze objects, are the main

${ }^{1}$ I am using 'elementary education' to refer to the process of acquiring basic literacy and numeracy, while leaving open what form it took and where it took place. Cribiore 1996; Cribiore 2001: 2-6.

2 Harris 1989: 158-9; Cribiore 2001: 4; Horster 2011: 85.

${ }^{3}$ Many of the standard works on ancient Mediterranean education and literacy deal only with sources in Greek or Latin: Morgan 1998; Hemelrijk 1999. Horster 2011 deals only with Greek and Latin, and assumes that the majority of ancient people were monolingual, which is crossculturally unlikely: Clackson 2012: 47-8; Dickey 2012: 4. Bowman and Woolf 1994 covers a wide chronological and geographical range, touching on a variety of languages. Cribiore 1996, Cribiore 2001 and Bucking 2012 mention Coptic in their discussions of education in Egypt. The Etruscan context for Roman literacy is mentioned more frequently than the other languages of Italy: see Stoddart and Whitley 1988; Habinek 2011. Maras 2015 provides Etruscan, Venetic and other Italian context for Roman literacy; Bloomer also mentions Venetic briefly alongside his discussion of Etruscan (Bloomer 2011: 18-21). Harris speculates briefly about the possibility of high literacy levels in Oscan-speaking areas of Italy, but without good evidence (Harris 1989: 266): see McDonald 2015: 47-8. 
dedications, and as a result Reitia is sometimes described as the 'goddess of writing'. 4 These unique inscribed votives are not often cited in wider discussions about ancient education, but they can provide key evidence for teaching and learning methods in Italy, the social groups who had access to basic literacy, and learners' attitudes to acquiring literacy.

After an overview of the content, layout and main features of the dedications, I will explore how these objects function as votives, with reference to the wider Italian culture of votive dedications in this period. While no direct comparanda exist for the dedication of bronze writing implements with such elaborate writing exercises, this article will also explore other sites and texts in the ancient Mediterranean where alphabets appear in funerary and votive contexts, showing that there was a wide spectrum of dedicatory habits involving abecedaria and writing tools across the ancient Mediterranean. I will also suggest that the dedication of bronze writing tablets and styluses was a specifically elite activity, and that other lower-cost parallel forms of dedication may have been performed at Este and elsewhere, such as the dedication of wooden writing tablets.

Secondly, I will compare these Venetic texts to surviving Greek writing exercises of a similar period. This comparison will show that the Venetic texts fit into a wider Mediterranean context, and are a plausible representation of ancient education practices. As such, they are among the earliest pieces of extant evidence for the methods of teaching basic alphabetic literacy in Italy. A further thread which runs throughout this discussion is the strong link between Reitia, literacy and women. The large number of women named as dedicators in these texts suggests that women, or at least elite women, were actively engaged in the epigraphic habit of the city, and points towards an association between women and elementary literacy at this sanctuary site. This has important implications for our understanding of literacy in the Italian peninsula during this period, and suggests that elite women's literacy in pre-Roman and early Roman Italy may previously have been underestimated.

\section{DEDICATIONS TO REITIA}

\section{The Este-Baratella sanctuary}

Este and its neighbour Padua were the two largest urban centres in the Veneto region until the foundation of nearby Roman colonies in the second century B.C. (Fig. 1). The earliest

\footnotetext{
${ }^{4}$ Langslow 2012: 295.
} 
extant inscriptions ${ }^{5}$ from Este are dedicatory and funerary inscriptions dated to the second half of the sixth century; ${ }^{6}$ however, most of the inscriptions at Este in the Venetic alphabet date to 350-150 B.C. There is also a considerable corpus of Venetic inscriptions written in the Latin alphabet dating to 150-50 B.C. In total, around 250 extant Venetic inscriptions from Este survive. ${ }^{7}$

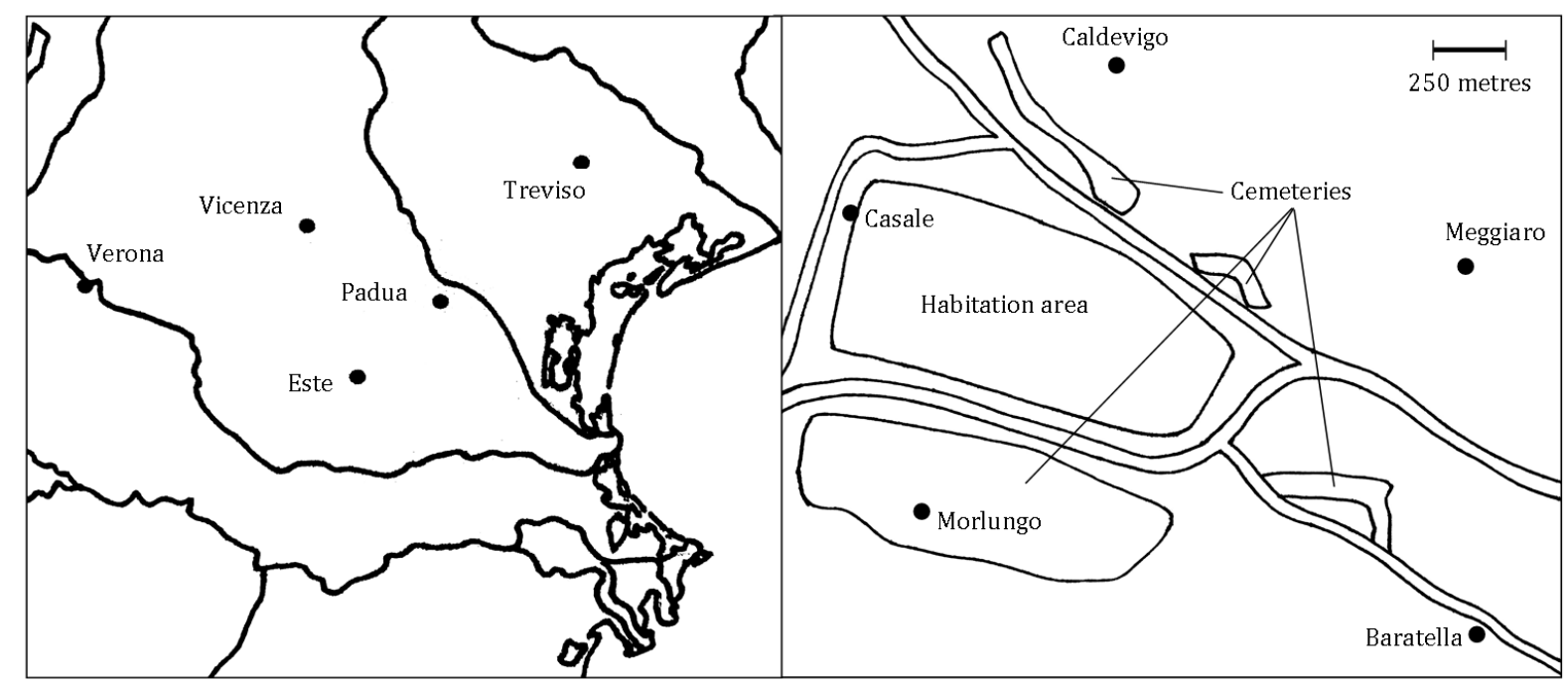

FIG. 1. Map of the Veneto region and schematic of the locations of sanctuaries in Este, after Balista and Ruta Serafina. ${ }^{8}$ (Drawing: author)

${ }^{5}$ Unless otherwise stated, inscription numbers refer to those in Pellegrini and Prosdocimi 1967. Numbers preceded by asterisks are from Fogolari and Prosdocimi 1988; more recently discovered Venetic texts, only a handful of which are from Este (Marinetti 1998: 53), are given with references to their publications. In accordance with current practice, texts in the Venetic or Etruscan alphabets are transcribed in bold, while texts in the Roman alphabet are transcribed in italics. When discussing linguistic details, /a/ refers to a phoneme (sound) and $<$ A $>$ refers to the shape of a written letter.

6 The earliest funerary inscriptions, both on stone cippi, both from the late sixth or early fifth century B.C., are Pellegrini and Prosdocimi 1967: Es 1; Marinetti 1999: \#1; the earliest dedicatory inscriptions, both sixth century or early fifth century, are Fogolari and Prosdocimi 1988: *Es 120; Marinetti 2004: \#1.

7 The dating of these inscriptions, which were discovered in the nineteenth century, is a continual problem. Much of the dating is an imperfect estimate based on letter shapes, as set out by Lejeune 1974. Usually the texts in the Venetic alphabet, including all but one of the inscriptions under discussion in this chapter, are dated to before 150 B.C.

8 Balista and Ruta Serafini 1992. 
Venetic was written in an adapted form of the Etruscan alphabet. It also derived some additional letters from the Greek alphabet to replace the letters representing the voiced stops and the vowel /o/, which had been dropped from Etruscan writing very early. ${ }^{9}$ Most of the writing system is common to the whole region, but some of the letter shapes used in different areas are distinctive - for example, the different shapes of the sign for / $\mathrm{t} /$ in Este and Padua. There was no single moment of transmission of the alphabet: Venetic writers stayed in touch with developments in Etruscan writing, including the emergence of a complex system of punctuation to mark any syllables not conforming to a C(onsonant)V(owel) structure. ${ }^{10}$ This system of punctuation was picked up in the Venetic writing system around the fifth century and then maintained until the first century B.C., far outliving its use in Etruscan. ${ }^{11}$ Around the late second or early first century, Venetic started to be written in the Latin alphabet, sometimes still maintaining its system of syllabic punctuation. After the settlement of Actium veterans at Este after 31 B.C., the written language of the site changed to Latin.

\footnotetext{
9 The Etruscan language lacked voiced stops (/b/, /g/ and /d/) and the vowel /o/. These letters are found in Etruscan 'model alphabets', such as the Marsiliana d'Albegna alphabet discussed below, but were not used to write Etruscan words, and eventually were dropped from abecedaria - such letters are called 'dead letters'. Venetic writers repurposed zeta to represent /d/, keeping zeta's usual place in the alphabet. They also repurposed Greek phi to represent /b/, chi (in the 'red' alphabet shape $<\Psi>$ common in Italy) to represent /g/, and omicron to represent /o/. These three letters appear at the end of the Venetic alphabet, showing them to be a later addition. The Venetic alphabet also includes both sigma and san, transcribed here as $\mathbf{s}$ and ś, which probably represent two different sibilant consonants. The sound /f/ is represented by the digraph $<\mathbf{f h}>$, as in early Etruscan writing.

10 In this system of punctuation, any syllable which consists of consonant + vowel is left unmarked. However, any syllables which end in a consonant, diphthongs, or syllables which consist only of a vowel, are marked by placing dots or short lines around the letter which causes the syllable not to conform to the CV structure. For example: .e.go vhu.k.s.siia.i.
} vo.l.tiio.m.mnina.i. (Es 2, funerary inscription on stone, 475-350 B.C.). 11 Prosdocimi 1983: 84-8; Wachter 1986; Bonfante and Bonfante 2002: 56; Marinetti 2004: \#1 may be one of the earliest Venetic inscriptions with syllabic punctuation. 
The city of Este was surrounded by five extra-mural sanctuaries (Fig. 1); the five sanctuaries each appear to have been dedicated to a different deity or set of deities. ${ }^{12}$ It has been hypothesised, based on the kinds of votives, that each sanctuary was also the religious focus for a different social group. ${ }^{13}$ For example, the dedications of female figurines and images of adult women may show that Baratella was the focus of cult activity for women; ${ }^{14}$ however, this is speculative, as this is the only sanctuary to provide inscribed dedications which name the deity or the people involved in dedicatory practices there. ${ }^{15}$ At Baratella, which was in active use as a sanctuary from the sixth century B.C. to the third century A.D., ${ }^{16}$ the deity was a goddess named Reitia. ${ }^{17}$

The vast majority of the dedications at Este-Baratella are uninscribed. ${ }^{18}$ These include bronze figurines, some of which depict human figures, especially equestrians. The Veneticspeaking area also had a tradition of dedicating bronze sheets, known as laminae, which were cut into shapes or inscribed with pictures (Fig. 2), some of which were local variants of the

12 Lomas 2009: 15-16; for example, one is sometimes described as the sanctuary of the Dioscuri: Capuis and Chieco Bianchi 1992: 93.

13 Pascucci 1990; Maggiani 2002.

14 Pascucci 1990: 59-92; Lomas 2009: 15-17.

15 One dedicatory text (Es 75), a stone obelisk, was found near the Calvedigo sanctuary area. Lejeune 1974: 212.

16 Capuis and Chieco Bianchi 1992: 93.

${ }^{17}$ She is also named as Śainatis Reitia and Śainatis Reitia Pora; the name Pora also appears alone, and in the combinations Śainatis Pora and Pora Vebelis. These names are all probably epithets of Reitia, although they may be other associated female deities. These names cause some transcription difficulties. In syllabic punctuation, the letter $<\mathbf{i}>$ is usually marked when it is the second element of a diphthong, so that it reads <.i. $>$, but after around 350 B.C., the sign for $/ \mathrm{h} /$ became a line with dots either side, making it identical in form to a punctuated letter <.i. $>$. Thus, in the names of the goddess there are several possible transcriptions: śa.i.nate.i. vs. śahnate.i. (cf. Latin sānus 'sound, healthy') and re.i.tia.i. vs. rehtia.i. (cf. Latin rectus, 'straight, upright'). In each of these examples, the former variant is now the more common transcription (and is used in this article), based on Lejeune's transcription, even though the latter variant has a better possible etymology. Conway 1916: 228; Lejeune 1974: 328.

18 Capuis and Chieco Bianchi 1992: 96-9. 
common 'anatomical votive' tradition found across Italy at this time. ${ }^{19}$ Other dedications include three-dimensional bronze anatomical votives, which are similar to terracotta examples found elsewhere. ${ }^{20}$ The Atestine use of bronze for types of votives which were typically made of other materials elsewhere in Italy will be revisited in Part III, below.

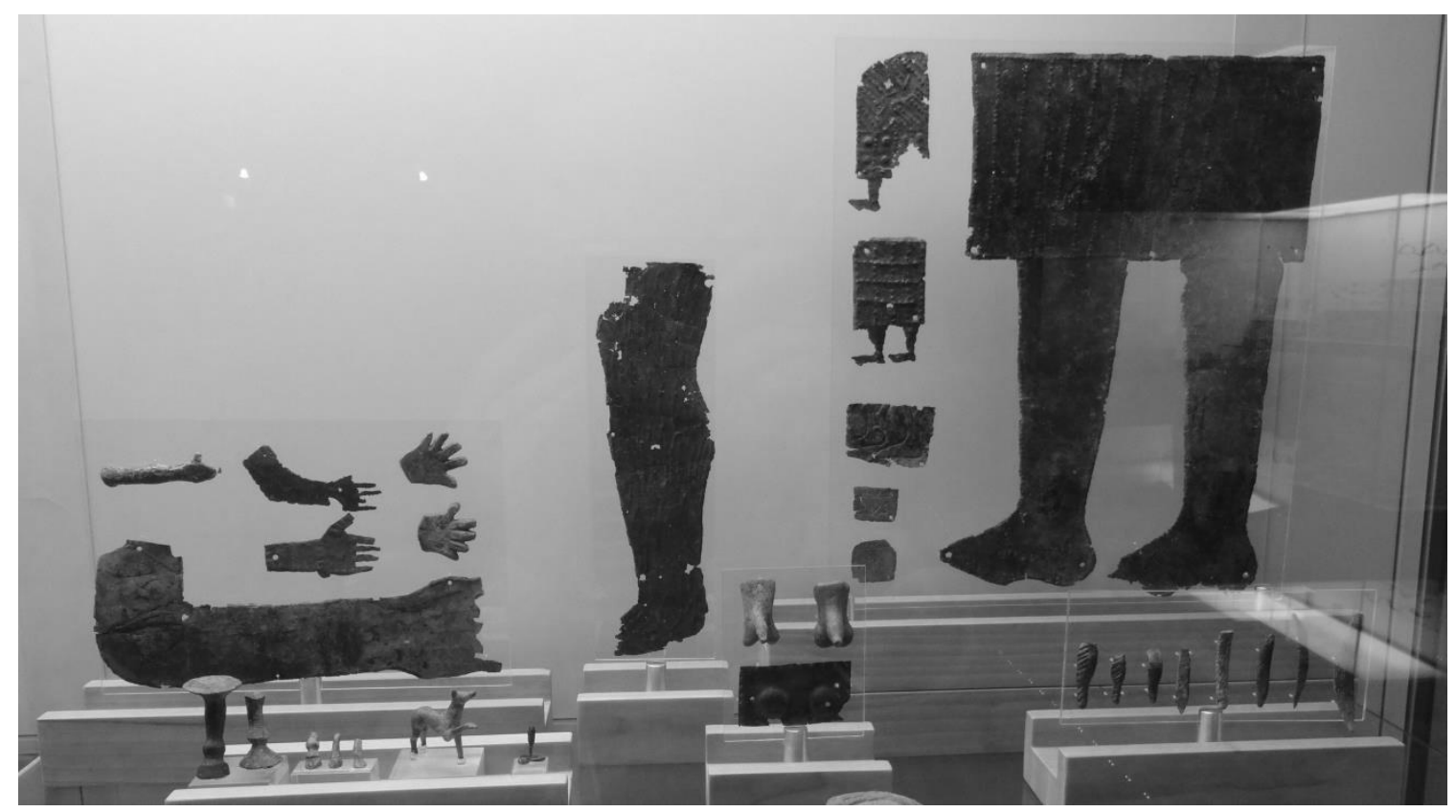

FIG 2. Bronze anatomical laminae from Este-Baratella. Museo Nazionale Atestino. (Photogragh: author)

Three main forms of inscribed dedication are found at the Baratella sanctuary: inscribed stone statue bases, bronze tablets and bronze styluses. The eleven small stone statue bases were all dedicated by men; the bronze statues originally attached to these

19 This is sometimes referred to as the 'Etrusco-Latial-Campanian' votive tradition, although aspects of it formed a larger Italian koine. Graham 2014: 24; Graham 2017: 45; Glinister 2006: 26; Turfa 2006: 94.

${ }^{20}$ Elsewhere in Italy, deities commonly honoured with anatomical votives are often female deities connected to water or fertility, as in the offerings to a goddess (probably Mefitis or Feronia) at Fregellae, or Uni, Mater Matuta, Diana and Ceres elsewhere. Female images of dedicants (whether in the form of statuettes or heads) are typically more common than male at such sites, suggesting that these offerings were disproportionately made by women. Graham 2017: 45; Glinister 2006: 29. 
pedestals no longer survive, but one inscription indicates that they were statues of horses. ${ }^{21}$ These statue bases show an aspect of Reitia which is not linked to literacy or to women, and it is important to keep in mind that Baratella was a sanctuary with a range of purposes, though this article will focus on the bronze inscribed dedications.

\section{Bronze writing tablets}

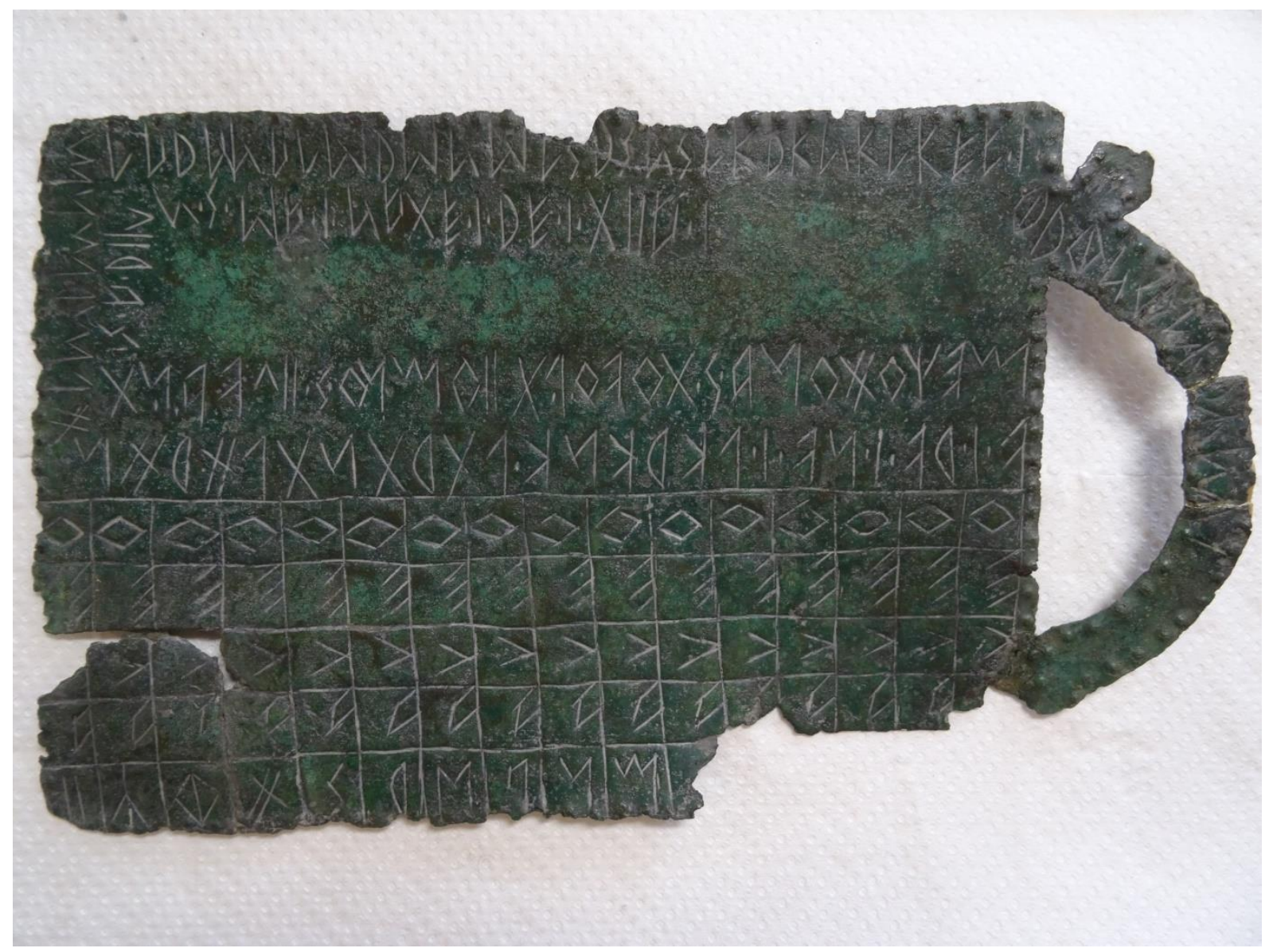

FIG. 3: Es 25. 350-150 B.C. Museo Nazionale Atestino. (Photograph: author)

21 .e.[ca.3].s. e.kvo[.]n[.] dona.s.to re.i.ti[ia.i.] mego '[Male name ending -s] gave me, a horse, to Reitia.' (Es 71, stone pedestal, 350-150 B.C.). This is consistent with the shapes of the holes on the pedestals. Seven of the eleven stone pedestals are dedicated to Reitia, Pora or Sainatis; one does not name a recipient and three are incomplete. 


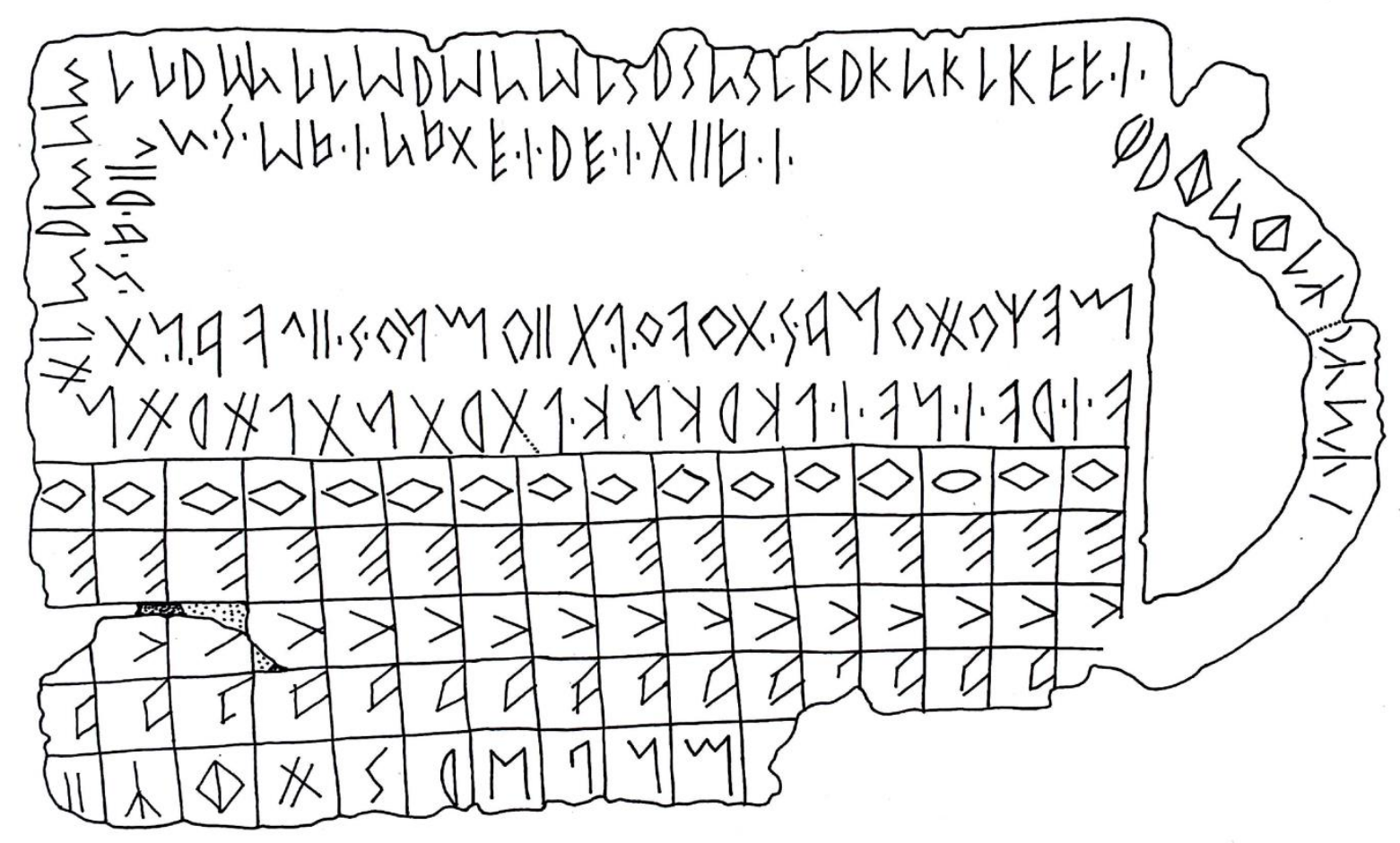

FIG. 4: Es 25. 350-150 B.C. (Drawing: author)

This group of inscriptions is made up of bronze writing tablets (Figs 3 and 4), presumably purpose-made for dedicating to the goddess Reitia or related deities at the Baratella sanctuary near Este. 22 Except for Es 29, they have all been dated to around 350-150 B.C., mainly based on the form of the Venetic alphabet which they use. ${ }^{23}$ Es 29 is written in the Venetic language using the Roman alphabet, and is dated to around 150-50; Es 27 includes a Latin-language dedication formula and a Latin writing exercise, and may date to 200-150. Nine of the tablets are near complete (Es 23, 24, 25, 26, 27, 28, 29, 30, 31), while eight are more fragmentary (Es $32,33,34,35,36,37,38,39$ ); where the tablets are complete enough that their dimensions

22 Most of the tablets (and other materials from the sanctuary) were discovered in the $1880 \mathrm{~s}$ by the landowner, Luigi Baratella; Ghirardini managed to convey the artefacts found to the Museo Civico, now the Museo Nazionale Atestino, and described the finds in two detailed publications, but he was not able to describe the findspots or stratigraphy in detail. Ghirardini 1888a; Ghirardini 1888b; Capuis and Chieco Bianchi 1992: 93.

${ }^{23}$ Namely, they use syllabic punctuation (probably introduced around the beginning of the fourth century B.C.) and they all use /h/ written in the later form of a line surrounded by two dots. This dating system was proposed by Lejeune 1974: 21, though he advocates for flexibility within this system. 
can be determined, they measure approximately $95-165 \mathrm{~mm}$ in width and $128-200 \mathrm{~mm}$ in length. ${ }^{24}$ Some were found folded, so that there are lines of damage to the texts, and some surfaces were oxidised. ${ }^{25}$ The most complete tablets are rectangular, or rectangular with a semi-circular 'handle' attached to one of the sides, mimicking real writing tablets, to which bronze handles could be attached..$^{26}$

The texts inscribed on the tablets contain a mixture of elements, some of which look like writing exercises, and some of which specify that the purpose of the text is dedicatory. There are five typical elements, which occur in various combinations:

(1) a list of consonants in alphabetical order, often with one vowel at the end to bring the total to sixteen;

(2) the formula a ke o, written upwards and usually repeated sixteen times;

(3) the alphabet, in alphabetical order;

(4) a list of consonant clusters which do not require syllabic punctuation;

(5) a dedication formula using the verb donasto 'gave', usually naming the dedicator and the deity, and sometimes giving additional circumstances of the dedication.

Element (1), the consonant list, runs $\mathbf{v} \mathbf{d} \mathbf{h} \boldsymbol{\theta} \mathbf{k} \mathbf{l} \mathbf{m} \mathbf{n} \mathbf{p}$ ś $\mathbf{r} \mathbf{s} \mathbf{t} \mathbf{b} \mathbf{g}$, and usually appears at the bottom of the tablet. ${ }^{27}$ This includes $\boldsymbol{\theta}$ which is a dead letter at Este and most other Venetic-speaking sites - that is, it is found in abecedaria but is never used to write words. This alphabetical order suggests the rote learning of a model alphabet, which persisted for at least several generations after $\boldsymbol{\theta}$ dropped out of use. The Marsiliana d'Albegna abecedarium (discussed below, Part III) shows evidence of a similar phenomenon in Etruscan education. On several tablets (Es 23, 24, 25, 26), the list of consonants is divided up into a grid of sixteen

\footnotetext{
${ }^{24}$ Sixteen small text fragments also appear to belong to dedication tablets (Es $39 \alpha-\kappa ; *$ Es a-f). 25 Ghirardini 1888a: 8.

${ }^{26}$ Surviving examples of students' writing tablets with metal handles include a wooden tablet in the British Museum (BM 1906,1020.2). A fifth-century B.C. Attic kylix shows two girls (on their way to school?), one of whom carries a writing tablet by its handle (Metropolitan Museum of Art 06.1021.167).

27 Venetic texts often begin at the bottom right of the available space, and read right-to-left. Texts can be 'false boustrophedon', where the text is written in a circle or spiral, so that the lines are upside-down in relation to each other and the direction of writing does not actually change.
} 
boxes. Since there are only fifteen consonants in the Venetic alphabet, the last box is normally filled with one more sign. For Es 23 and 24, the extra sign is e, for Es 25 it is ii (probably representing the digraph for consonantal yod) and for Es 26 it is a. It is possible that the vowel was chosen at random, though the digraph $<\mathbf{i i}>$ is a choice that indicates that yod could be considered be an extra consonant. This represents an adaptation of the (presumed) underlying Etruscan model to suit Venetic, since there was no phonemic consonantal yod in Etruscan. ${ }^{28}$

Element (2) is the formula a ke o, which normally appears in lines 2-5 of the inscription: it appears as one line of the repeated letter $\mathbf{a}$, a second line of $\mathbf{k}$, a third line of $\mathbf{e}$, and a fourth line of $\mathbf{o}$, with each letter written 16 times. The significance of these letters has been debated in past work. The most convincing explanation is that the formula is ' $\mathrm{A}$ and $\mathrm{O}$ ', the first and last letters of the Venetic alphabet: ${ }^{29}$ though ke lacks a clear etymology, its use as a coordinating conjunction is unambiguous. ${ }^{30}$ The phrase may have some magical or ritual significance, rather than being a learners' exercise. ${ }^{31}$

28 My thanks to an anonymous JRS reviewer for this suggestion.

${ }^{29}$ Haas 1952; Lejeune 1952; Lejeune 1974: 189; Prosdocimi 1983: 89. Cf. Christian 'alpha and omega'.

30 The conjunction ke appears elsewhere joining two verbs (Es 27) and joining a personal name with the word 'children' (Es 45). Lejeune 1974: 72-3.

${ }^{31}$ Prosdocimi 1983: 98. An alternative explanation for this sequence, which in some ways brings it closer into line with other known educational texts, is that instead of reading the second line as k, it should be read as a rotated $\mathbf{u}$ : Rix 1960: 124-39; Pellegrini and Prosdocimi 1967: 102. If this is correct, this element consists of sixteen repetitions of each vowel except $\mathbf{i}$. The exclusion of one of the vowels could perhaps be justified by the fact that Etruscan has only four vowels: if this series of writing exercises was adapted from Etruscan culture, at some point $\mathbf{o}$ might have been introduced and $\mathbf{i}$ dropped from the exercise (many thanks to Daniele Maras). Alternatively, following Prosdocimi 1983: 89, the $<\mathrm{K}>$ shape could be a ligature of $\mathbf{i}$ and $\mathbf{u}$, if the $\mathbf{u}$ were rotated. There is a certain logic in having (1) a consonantal alphabet, then (2) the vowels and then (3) a full alphabet. However, the lack of a clear justification for the exclusion of $\mathbf{i}$ weakens this explanation. Reading $\mathbf{u}$ rotated by $90^{\circ}$ compared to the other characters is also problematic, although on some tablets (e.g. Es 25, Figs 3 and 4) the letter < $>$ also appears to be rotated compared to the other letters on the 
Element (3), the abecedarium, shows the full alphabetical order used in Venetic: a e v d h $\boldsymbol{\theta} \mathbf{~ k ~} \mathbf{l} \mathbf{m} \mathbf{n}$ śs $\mathbf{r} \mathbf{t} \mathbf{u} \mathbf{b} \mathbf{g}$. As in element (1), the letter theta is included even though it was a dead letter at Este. While Es 23 is the only example of a tablet which preserves the full Venetic alphabet, ${ }^{32}$ two examples, Es 29 and Es 27, probably from the latest end of this corpus, include the Roman alphabet. Es 29 consists only of a dedication formula and an abecedarium. As the inscription does not include $y$ and $z$, it was therefore probably written before the Augustan period: [a] bc defghi klm nopqrst $v x$. In the Roman alphabet on Es 27, the letters appear out of order, taking the letters from each end of the alphabet in turn and working towards the middle. This reconstruction was proposed by Prosdocimi on the basis of techniques described by Quintilian, who advised teachers to scramble the letters out of sequence to make sure they had been fully learned (see Part IV, below). ${ }^{33}$ If this abecedarium is correctly reconstructed, then this represents key early evidence for Latin-language as well as Venetic-language elementary education at this site, as well as possible evidence for bilingual education. ${ }^{34}$

Element (4), a list of consonant clusters, appears on most of the tablets (Es 23, 24, 25, $26,31,32,33,34,39$ ) in a similar but not identical order, and the clusters are not the same on every tablet.

Es 23: [v]hr vhn vhl vh dr dn [d]l $\theta$ r $\theta$ n $\theta 1$ kr < k>n kl kv mr mn ml pr pn pl śr śn śl sr sn sl tr tn tl br bn bl gr gn gl

tablet. Ultimately, this alternative explanation has both advantages and disadvantages, and it should be kept under consideration.

32 This use of the alphabet is sometimes also described as 'magical'. Lejeune 1952; Pellegrini and Prosdocimi 1967: 103; for the use of magical amulets in the Veneto: Perego 2010.

33 Prosdocimi 1983: 95-8; Langslow 2002: 34-5; Langslow 2012: 295.

34 Our interpretation of this tablet depends on (a) the dating of the tablet and (b) the relative dates of the Venetic and Latin elements. The tablet has usually been tentatively dated to the second century B.C., based on the perceived likelihood of Latin and Venetic being used simultaneously. However, it is possible that the Latin could have been added later. This is relatively unlikely - the Latin dedication occurs in the middle of the Venetic text - but it is very difficult to determine whether the two texts are in different hands, and the element that Prosdocimi identifies as a Roman alphabet is extremely fragmentary. Langslow accepts this as a bi-version bilingual text showing both Venetic and Roman teaching traditions (Langslow 2002; 2012). 
Es 24: [v]hr vhn vhl vh dr dn dl $\theta$ r $\theta$ n $\theta 1$ kr kn kl kv mr mn m[l] pr pn pl śr [śn ś]l sr sn sl tr tn tl br bn [b]l gr gn gl

Es 25: vhr vhn vhl kr kn kl $\boldsymbol{\theta r}$ Өn $\theta \mathbf{l}$ dr dn dl mr mn ml pr pn pl śr śn śl sr sn sl kr kn kl kv vh br bn bl gr gn gl

Es 26: vhr v[hn vhl vh] tr tn tl kr kn k[l mr mn ml] pr pn pl śr śn śl sr sn [sl] dr dn dl br bn bl gr gn gl kv

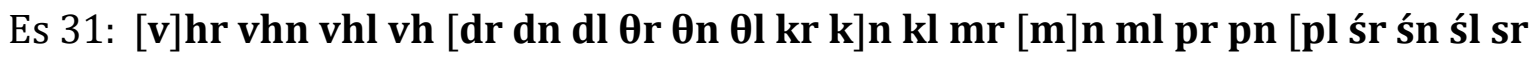
sn sl tr] tn tl br bn bl gr gn g[l]

Es 32: ]sr sl t $\mathbf{t}[\mathbf{n}$

Es 33: ] kn kr [

Es 34: [vhr vhn vhl vh? dr d]n dl $\theta$ r $\theta$ n $\theta 1$ kr k[n kl kv? mr mn ml pr pn pl śr śn] śl sr sn sl tr tn tl br bn bl g[r gn gl]

Es 39: [kl k]n kr [----- / ----- ś]l śn [śr ----- / -----] b[

These clusters are not randomly chosen: they are the consonant clusters which do not require special marking under the Venetic syllabic punctuation system. ${ }^{35}$ This would, no doubt, have been something that required practice when learning to write in the Venetic alphabet, and therefore they make a very plausible writing exercise for learners. It is also possible that these clusters show some evidence of independent developments away from the Etruscan model for the exercise. For example, the sequence tends to have b- and g- clusters towards the end of the list, in accordance with Venetic rather than Etruscan alphabetical order, although the sequence is not always strictly alphabetical. That said, this cluster list may continue to adhere to an underlying Etruscan model in some respects, despite differences in Venetic writing habits. For example, there are no clusters with i/ii (yod) listed, although syllables like siio and tiio tend to be unpunctuated in Venetic texts. ${ }^{36}$

\footnotetext{
35 Beeler 1949: 11; Lejeune 1950; Prosdocimi 1990: 182-4.

36 Many thanks to an anonymous JRS reviewer for making this suggestion. The interpretation of the sequences with yod is not completely straightforward, as the phoneme system of Venetic is not always clear and both the spellings and punctuation are inconsistent. Sequences like -tiio- in vo.l.tiio.m.mnina.i. (Es 2) may represent a cluster /tjo/ but might equally represent /tijo/ in some or all circumstances, assuming that any spelling -iii- was routinely simplified to -ii-. There is variation in whether yod is spelt $\mathbf{i i}$ or $\mathbf{i}$, which also confuses this issue, although ii is used around 60 per cent of the time. Lejeune 1974: 33, 131. In a few
} 
In several examples (Es 23, 24, 25, 34), $\boldsymbol{\theta}$ has been included in the list of consonant clusters despite its status as a dead letter. In Es 26, though, theta has been missed out, $\mathbf{t}$ has been moved to the position normally taken by theta, and $\mathbf{d}$ has been moved to the position usually taken by $\mathbf{t}$. The consonant cluster list in Es 26 therefore differs in alphabetical order from its consonant list, which includes theta. This may show the clash of two slightly different alphabetical orders which were current at the same time - the model alphabet vs. the alphabet for everyday use - again perhaps showing signs of deliberate adaptation of the educational exercises to fit Venetic writing habits.

Element (5) is the dedicatory formula, ${ }^{37}$ which most commonly consists of (a) a verb, usually dona.s.to 'gave' but also doto 'gave',38 or the two coordinated verbs [do]na.s.to ke la.g.[s.to] (Es 27), ${ }^{39}$ and (b) an accusative naming the inscription, usually mego 'me' or vda.n. 'alphabet'. ${ }^{40}$ Typically, the inscriptions also name a dedicator and the deity to whom they are dedicated, but these elements are not compulsory. A few mention relationships between individuals, such as <v>ḥratere.i. 'brother' (Es 28) and lo.u.derobo.s. 'children' (Es 45). Some also have additional information about the circumstances of the dedication, including phrases of uncertain meaning such as .o.p vo.l.tiio 'because of a voluntary (act) (?)' (*Es 125), o.p. vo.l.tiio leno 'because of a voluntary act (?)' (Es 27, Es 32, Es 44) and o.p. iorobo.s. 'because of [dative plural noun]' (Es 23, Es 69). ${ }^{41} \mathrm{~A}$ typical formula (Es 23), naming both the dedicator and the divine recipient, reads as follows:

inscriptions outside Este (Vi 2, Ca 9), siio sequences are marked, which suggests that these spellings represented consonant clusters at least in some words.

37 For dedicatory formulae in Venetic: Lejeune 1974: 68-9.

38 For the two formations from the ${ }^{*} d \bar{o}$ - stem: Lejeune 1974: 80.

39 The second of these is another third-person singular preterite verb. Lejeune 1974: 385.

40 This meaning is inferred from the fact that the word vda.n. appears most often on the writing tablets, and the fact that the first two consonants of the Venetic alphabet are vd. This word therefore appears to be an a-stem noun constructed from the first two letters of the alphabet. Cf. names for alphabet in other languages, including the word 'alphabet', which are a nominalised form of the first two letters or first two consonants. Prosdocimi 1983: 116-7; Fogolari and Prosdocimi 1988: 266-7.

41 The phrase o.p. vo.l.tiio leno may parallel the Latin libens merito, which is found in the Latin formula on Es 27: Pellegrini and Prosdocimi 1967: 272; Langslow 2002: 34. However, the etymology is uncertain. Lejeune suggested vo.l.tiio < *wl-ti- 'voluntary': Lejeune 1974: 
mego dona.s.to .e.b. vhaba.i.tśa pora.i. o.p iorobo.s.

I-acc.sing. give-aor.3.sing. unknown.abbreviation Fabaitśa-nom. Pora-dat. because.of unknown-dat.pl.

Fabaitśa gave me to Pora [abbreviation] because of [plural ?deity]

The layout of the text as a whole shows the prominence of the writing exercises in the text. The complete text of Es 23 is as follows: ${ }^{42}$

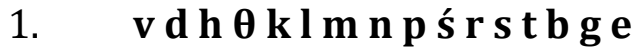

a a a a a a a a a a a a

k k k k k k k k k k k k k k

e e e e e e e e e e e e

$5 . \quad$ o 000000000000000

mego dona.s.to .e. b. vhaba.i.tśa p/ora.i. o.p ior/obos

a e. v. .d. h .ө. k. [l] m. <n> .p. .ś. r. .s. .t. .u. .b. .g. .o.

[v]hr vhn vhl vh dr dn [d]l $\theta$

r $\theta \mathbf{n}$ Өl kr $<$ k $>$ n kl kv mr mn ml

10. pr pn pl śr śn śl sr sn sl

tr tn tl br bn bl gr gn gl

341; leno < *wle--no- 'voluntary act': Lejeune 1974: 336. Zavaroni has recently suggested an alternative interpretation: 'for good health' pro bona ualetudine, cf. Latin ualeo and perhaps Oscan ualaemo: Zavaroni 2008. The letters .e.b. (Es 23, Es 43, maybe Es 58) may also be an abbreviated formula.

42 An alternative interpretation of the word division is found in Marinetti 1990: 101. 


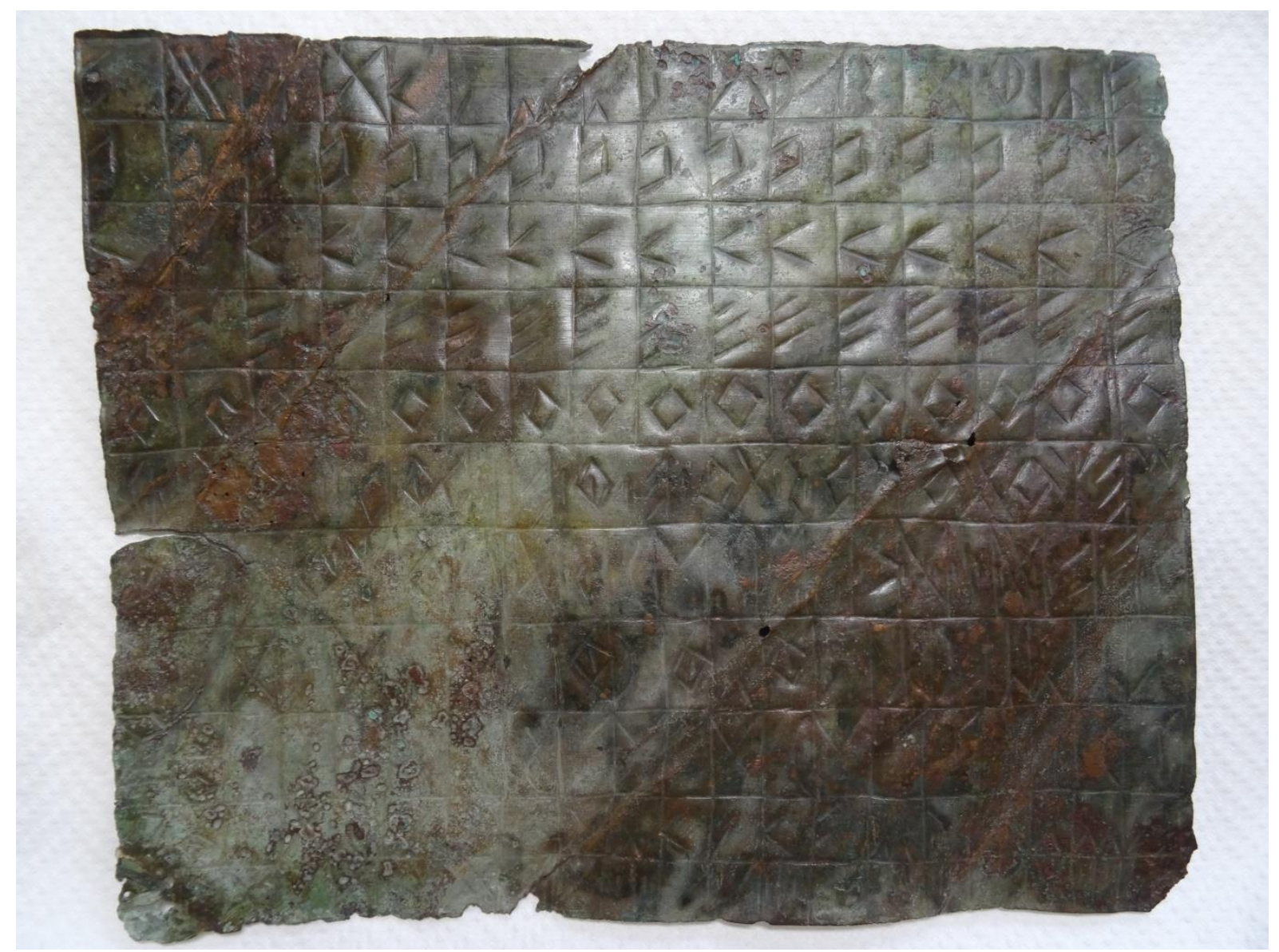

FIG. 5. Es 23. 350-150 B.C. Museo Nazionale Atestino. (Photograph: author) 


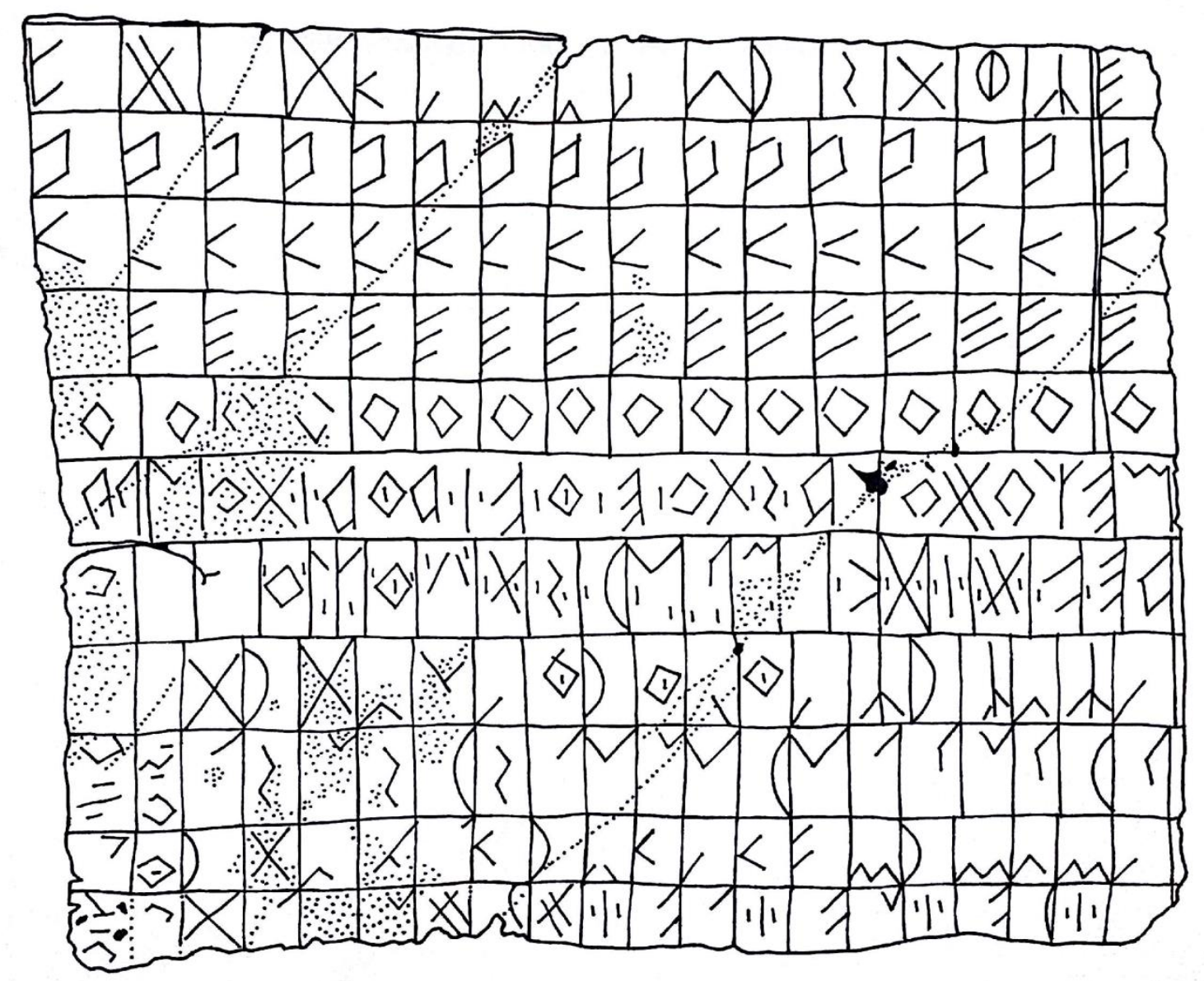

FIG. 6. Es 23. 350-150 B.C. (Drawing: author)

This transcription starts at the top left of the drawing (see schematic in Fig. 7). There are several changes of direction - for example, a ke o is read across lines 2 to 4 - and of orientation, so that the tablet needs to be rotated to read all the elements. ${ }^{43}$ Line 6 , for example, turns a corner twice, and the reader would need to turn the tablet to read it easily. This may show how wax tablets were used by learners, but it is also possible that this was an elaboration of the writing exercises for decorative purposes or for some other reason connected to the process of dedication and was not typical of learners' writing. ${ }^{4}$

\footnotetext{
43 This drawing is presented so that the dedicatory formula in line 6 is in the correct orientation (right-to-left), which means that lines 1-5 are upside-down. 44 Prosdocimi 1983: 98.
} 


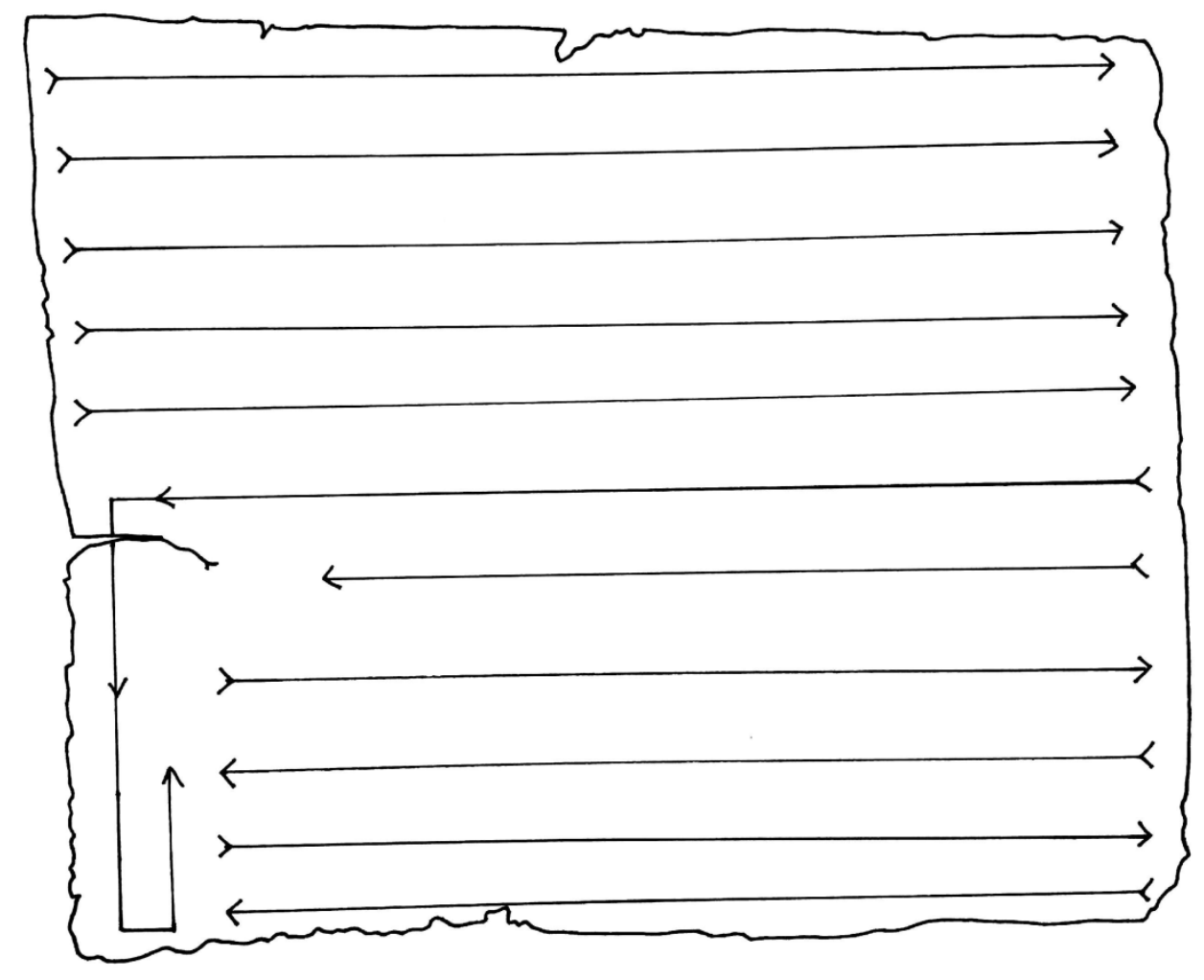

FIG. 7. Schematic of direction of writing in Es 23. (Drawing: author)

\section{Bronze styluses}

Another common form of dedication at the Baratella sanctuary is the bronze stylus. ${ }^{45}$ There are twenty-five inscribed styluses, and many pseudo-inscribed examples. They are oversized, mostly ranging from 175-260 $\mathrm{mm}$ long, suggesting that they are purpose-made dedications rather than real styluses (see Part III); the largest examples would be heavy and unwieldly for everyday writing. ${ }^{46}$ The styluses do not have the alphabets, consonant lists and consonant

45 Sometimes these objects are described as 'wedges' (Italian chiodi) rather than styluses. Some scholarship, particularly in the early twentieth century, described these as nails, or even hair pins (spilloni): Conway 1916; Whatmough 1922; Ghirardini 1888a; Prosdocimi 1990: 260.

46 To give a sample for comparison, the British Museum Greek and Roman Antiquities department has 105 unbroken styluses for which the length is listed in their catalogue. These range in length from $38-195 \mathrm{~mm}$; the mean length is $111 \mathrm{~mm}$; the median is $114 \mathrm{~mm}$. Only six examples are above $160 \mathrm{~mm}$, and only the very largest one is above $175 \mathrm{~mm}$. These examples are of different materials (including bronze, iron, copper alloy, wood, ivory, bone and lead), 
clusters found on the writing tablets, but their dedicatory formulae are the same. A typical example (Figs 8 and 9):

Es 44

mego doto vhu.g.siia votna śa.i.nate.i. re.i.tiia.i. o.p vo.l.tiio leno

I-acc.sing. give-aorist.3.sing. Fugsiia-nom. Votna-nom. Śainatis-dat. Reitiia-dat.

because of voluntary-instrumental.sing. act-instrumental.sing.

Fugsiia Votna gives me to Śainatis Reitia because of a voluntary act.

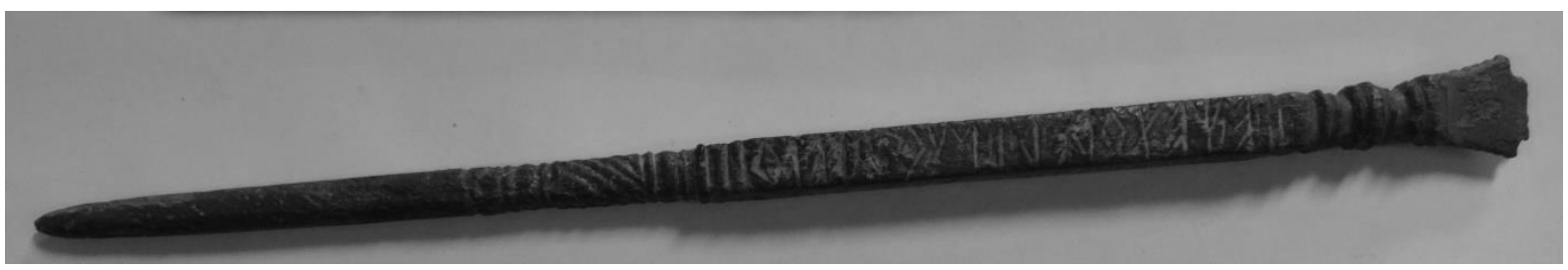

FIG. 8. Es 45. 350-150 B.C. Museo Nazionale Atestino. (Photograph: author)

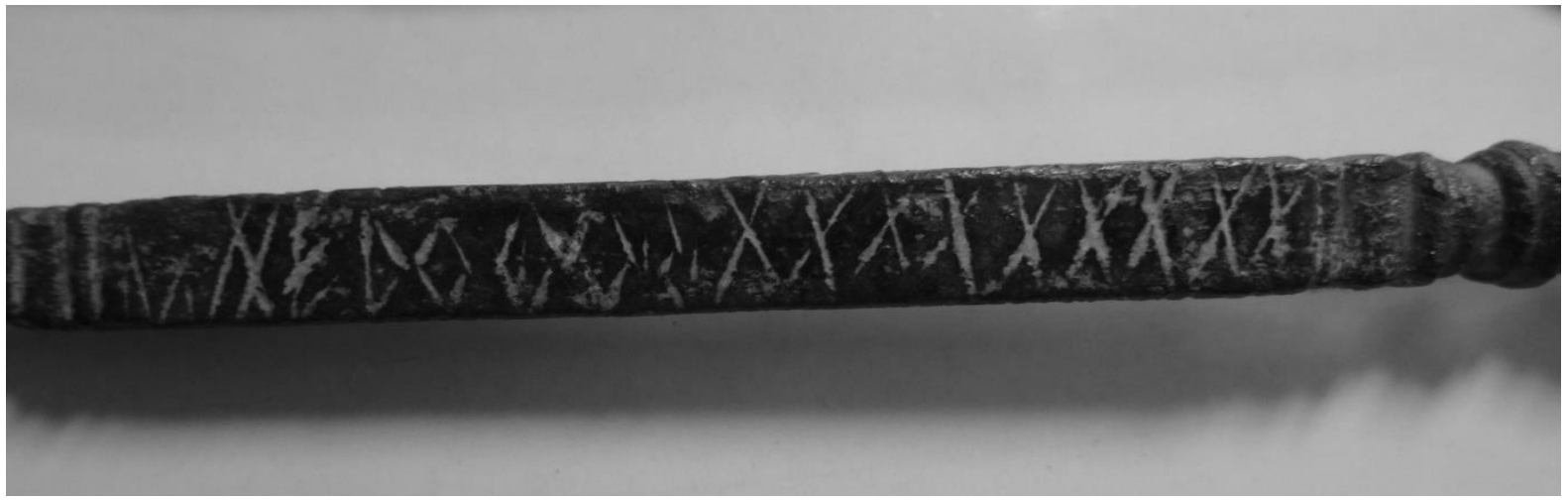

FIG. 9. Es 45. 350-150 B.C. Close-up of side 4. Museo Nazionale Atestino. (Photograph: author)

The pseudo-inscribed examples are decorated with symbols which, in some cases, look like repeated letters of the alphabet, such as the repetition of $<\mathrm{XXXXX}>$ (or, in Este's alphabet, ttttt) along the length of the stylus. In these cases, these may be real repetitions of significant letters of the alphabet rather than pseudo-writing, as we see on the writing tablets with a ke o. If these letters are meant as $\mathbf{t}$, its appearance on many of the styluses might be meaningful. Several of the inscribed examples of dedicatory styluses also have extra letters filling up empty space at the ends of lines, or filling the sides that are left uninscribed. For example:

Es 45

from a wide geographical and chronological range, but they give an idea of the lengths of usable styluses. 


\section{Side 1 mego dona.s.to śa.i.-}

\section{Side 2 nate.i. re.i.tiia.i. pora.i.}

Side 3 .e.getora .r.i.mo.i. ke lo-

Side 4 .u.derobo.s. ttttttttt

Egetora gave me to Śainatis Reitiia Pora for Rimos and (their) children. XXXXXXXXX

\section{WRITING AND WRITING TOOLS AS VOTIVE DEDICATIONS}

Dedications ${ }^{47}$ come in many forms: two distinctions which are relevant to this discussion are (a) whether or not the votives were purpose-made for dedication, and (b) the occasion or stage in the human-divine relationship at which they were dedicated. I will argue that it is likely that the bronze tablets and styluses were purpose-made and represent only the most expensive and durable end of a wider practice of dedicating writing equipment at EsteBaratella and, perhaps, more widely in Italy. We cannot tell, however, whether they mark the achievement of basic literacy, an aspiration to learn, or some other occasion.

\section{Dedications of writing tools - purpose-made or non-purpose made?}

Votive dedications can be divided into 'purpose-made' and 'non-purpose-made' (to use Hughes' terminology). ${ }^{48}$ 'Purpose-made' dedications are produced to be used as such, and have no previous existence. In many cases, these dedications were produced by craftsmen near the sanctuary, sometimes using mass-production techniques; they range from small and affordable to large and elaborate, but always involve an economic outlay for the dedicant. Non-purpose-made votives include personal belongings such as tools, clothing, jewellery, loom-weights, hairpins, toys, weapons, tools and hair, and whatever their intrinsic value, they do not normally involve any new economic outlay for the dedicant. Many non-purpose-made votives were of perishable material, and so these types of offering are often less archaeologically visible. ${ }^{49}$ It is possible that some of the styluses were non-purpose-made votives. However, as shown above, it seems likely that these examples are purpose-made

\footnotetext{
${ }^{47}$ Dedication is the 'action(s) whereby goods are transferred from mortals to transcendent recipients' with the intention of forging or maintaining a human-divine relationship. Bodel 2009: 19.

48 Snodgrass 1989: 291-2; Turfa 2006: 105; Graham 2014: 41; Hughes 2017.

49 Hughes 2017: 194-5.
} 
oversized reproductions, made specifically for dedication with flat sides with enough space for a clear dedicatory inscription. Purpose-made or non-purpose-made styluses made of other materials, such as wood or bone, may also have been dedicated but do not survive.

The bronze writing tablets are more clearly purpose-made dedications - a bronze tablet of this kind could not genuinely be used for a writing exercise. However, the level of participation of the dedicant in the object's production is hard to gauge. In most of the extant examples, it would be possible for all of the writing apart from the dedicatory formula to come pre-prepared, with the formula added at the dedicant's request at the time of purchase. But it is also possible that the tablets were produced blank, and that the dedicant had more input into the exercises which were included, which might explain some of the differences in the abecedaria and lists of consonant clusters between the different tablets. The dedicatory formulae are often found in the middle of the text, and might have been difficult to add later in Es 23 (Figs 5-7), the last four lines of exercises seems to have been written to fit around the dedication formula, suggesting that dedicators were involved in commissioning the whole text in some cases. It is also likely that these bronze writing implements constitute only the most enduring end of a wider practice of dedicating real waxed or wooden tablets alongside the bronze imitations, which might more plausibly have been written in the dedicator's own hand.

To support the hypothesis that the bronze writing tablets were made alongside analogous non-purpose-made dedications, we need to consider other evidence of writing and writing implements as dedications. The written word can have a power which makes it - and the tools that produce it - appropriate dedications in its own right. 50 The dedication of writing implements is known from elsewhere in the ancient world; the literary evidence is meagre, and is mainly limited to epigram. For example, in the Greek Anthology, there are seven examples of dedications of writing tools (Anth. Pal. 6.63-8, 295). Six of these poems were composed much later, but the earliest and perhaps the original epigram on this theme is by Phanias, who lived around the second or first century B.C. and is thought to have lived in Italy. ${ }^{51}$ The dedicated items mentioned include lead, pens, rulers, ink wells and ink, all of which have clearly been heavily used: for example, pens are often described as 'blackened'.

50 This is different to the usual purpose of inscriptions on dedications, where the inscription is subsidiary to the main dedication, such as a statue, altar, piece of armour, or other object. In these situations, Habinek describes writing as giving agency and relevance beyond the immediate context of the act of dedication: Habinek 2011: 122-3.

51 Gow 1956. 
This provides a clear non-purpose-made comparandum for the purpose-made oversized, inscribed styluses found at Este-Baratella.

Writing tablets themselves are not mentioned as dedicated objects in the poems of the Greek Anthology. However, wax tablets would have been a common sight in many ancient sanctuaries because of their use as a written record of prayers or promises by the dedicants. ${ }^{52}$ They were a cheaper alternative to stone inscriptions at many Roman sanctuaries, but their lack of survival means that their range of uses as votives is not fully understood.

\section{When and why were writing materials dedicated?}

Votive offerings can be made before, during or after the god doing something favourable, or to commemorate various kinds of personal milestones. ${ }^{53}$ In the Greek Anthology, the dedicants of writing materials are all male scribes retiring from work. But this is not the only time in one's life at which a dedication of writing materials might be made. It is possible that dedications of tools could also be made to celebrate a new or long-standing skill. ${ }^{54}$ There are also literary examples of dedications of items other than writing tools to celebrate literacy, or particularly outstanding achievements in literacy: for example, in an epigram by Asclepiades (c. third century B.C.), Konnaros has won a writing competition, apparently among relatively early learners, in which his handwriting has been particularly praised. ${ }^{55}$ The dedication he makes to the Muses is not one of writing tools, but a comic mask which, perhaps, evokes the higherlevel literary education he will go on to receive now that he has mastered this stage. Though the evidence is limited, this suggests that acquisition of literacy, or particularly outstanding

\footnotetext{
52 Rüpke 2009.

53 Some scholars claim that ancient votives were always, or almost always, given after the god had completed their promise - for discussion, see: Bodel 2009: 20; Graham and Draycott 2017: 7. In practice, though, we can see that there were many variations on this pattern, and that dedications could commemorate many different occasions. Glinister 2006: 13. ${ }^{54}$ A dedication in celebration of a girl's newly achieved skill (weaving) is seen in Anth. Pal. 6.39, among others. At Taras, a mid-sixth-century graffito on an Attic black-figure cup (SEG 40.900) states that it is a prize for Melosa's outstanding skill in carding wool. 55 Anth. Pal. 6.308.
} 
achievements during elementary education, could conceivably be celebrated with dedications. ${ }^{56}$

The timing of the dedications of the bronze Venetic writing tablets is not clear: the dedications might be either aspirational or celebratory, but they are likely to have some connection to education. It is often, correctly, argued that the shapes of dedications should not be taken literally - e.g. an anatomical votive in the shape of an ear need not indicate earache ${ }^{57}$ - but dedications of writing materials were nevertheless chosen by the offerant to reflect something about their own life experience and their relationship with Reitia. Given that the main literary evidence for the dedication of writing materials is connected with professional writers, it would seem a stretch to claim that the dedicators of these texts had no involvement with literacy at all. In light of the available comparanda, we can at least say that it is possible that there was a wider practice at Este of dedicating writing tools to mark some kind of personal milestone, of which only the most expensive purpose-made bronze items survived.

\section{Writing exercises as prestige objects}

The Atestine practice of dedicating writing exercises suggests that the exercises were considered worthy of being dedicated to a deity, but ancient examples of an explicitly high value being placed on learners' exercises are not particularly common. However, there are a few clear examples of abecedaria and writing exercises being deliberately placed in votive or other ceremonial contexts, and these are worth considering alongside the examples from Este-Baratella. The most famous replica of a writing tablet is found in a funerary, rather than a dedicatory, context. The Marsiliana d'Albegna alphabet (Fig. 10) is an expensive, purposemade replica of a writing tablet, usually dated to the second or third quarter of the seventh century B.C. ${ }^{58}$ The tablet is sometimes discussed as though it was a real writing tablet which was buried with its user, because traces of wax remained on the central field when it was

\footnotetext{
56 In his brief pamphlet On the Education of Children, Plutarch, writing several centuries after the last of the Venetic dedications to Este, tells a somewhat moralising story about the dedication made by a barbarian woman, Eurydice, when she had finished learning to read her dedication refers particularly to the acquisition of letters (Plut., Mor. 14b-c). For the ideal of educated motherhood, see: Hemelrijk 1999: 64-71.

57 Graham 2017: 45.

58 Cristofani 1969: 103; Wallace 2008: 17; Maras 2015: 202.
} 
discovered. ${ }^{59}$ However, its very small size $(88 \times 50 \mathrm{~mm})$ makes this unlikely - it would be difficult for a learner to write more than one or two letters - and so it is more likely to have been purpose-made for burial.60 The tablet was found alongside other ivory writing implements, including small styluses and erasers. ${ }^{61}$ The alphabet written on the Marsiliana tablet is probably best understood as copy of a 'guide' alphabet written on the frame of a writing tablet to help the learner; this fits with the accounts of Plato and Quintilian, both of whom mention learners tracing example alphabets (see Part IV). This writing tablet shows the prestige associated with writing implements in Etruria during this early period, and shows that copies of these objects were produced in Italy for ritual purposes.

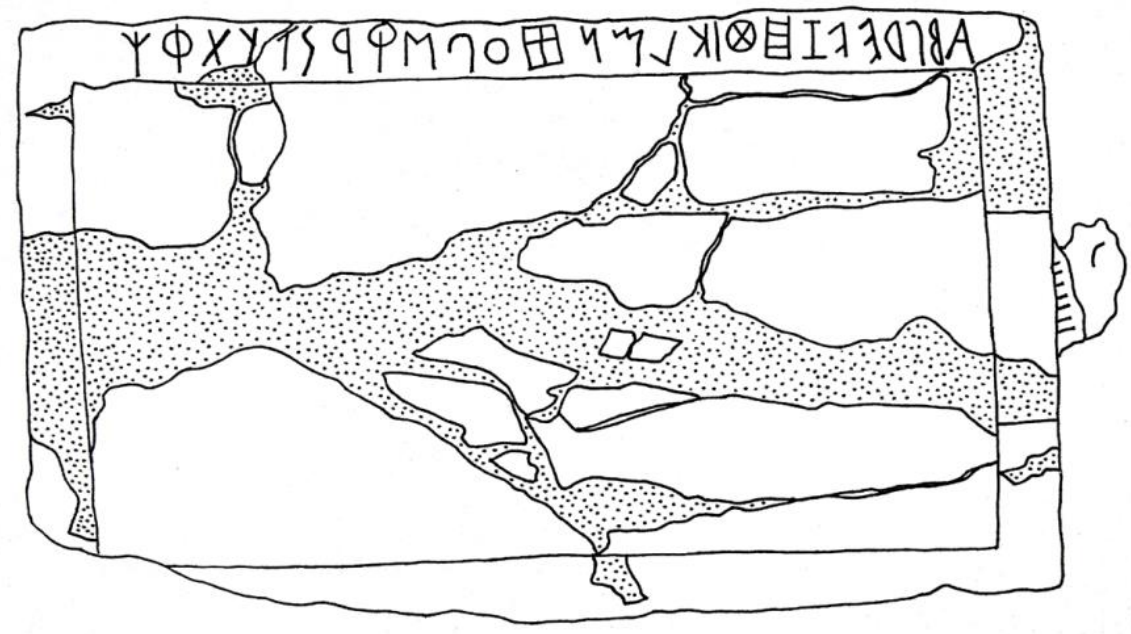

FIG. 10. Marsiliana d'Albegna writing tablet. (Drawing: author)

A number of other Etruscan texts show writing exercises on bucchero and other ceramic objects in elite burial contexts. ${ }^{62}$ Some include short formulae naming the owner alongside the abecedarium, e.g. Ve 9.4, while others include more elaborate writing exercises. For example, the Formello amphora, a bucchero amphora found near Veii in the same highstatus tomb as the famous Chigi vase, is inscribed with several texts: two abecedaria, a

\footnotetext{
59 Bundgård 1965: 12-15; Cristofani 1969: 113; Cornell 1991: 23.

60 Pandolfini and Prosdocimi 1990: 6; Bloomer calls it a 'deluxe miniature': Bloomer 2011: 19. ${ }^{61}$ Bonfante and Bonfante 2002: 21.

62 E.g. ET Ve 9.3, 9.4, 9.5; Cr 9.1, 9.2, 9.3. These texts appear to be written on complete vessels, not ostraka.
} 
formula indicating that it was a gift, and additional text which has been interpreted variously as a magical formula or writing exercises combining the letters $\mathbf{u}$ a r $\mathbf{z} \mathbf{s}^{63}$

A few texts also show short series of syllables, suggesting writing exercises: for example, the bucchero 'inkwell' from Caere, probably some kind of flask, also found in a burial context (probably the Regolini and Galassi tomb). ${ }^{64}$ This text has a full abecedarium, though $\mathbf{q}$ has been forgotten; $\mathbf{b}$ also faces backwards with respect to the other letters, suggesting that this is learner's writing. 65 There then follows a series of syllabic exercises, combining each vowel (in the order i a u e) with each consonant, at first in alphabetical order, though order breaks down at the end of the sequence. Dead letters are excluded from this syllabary. ${ }^{66} \mathrm{~A}$ small number of uninscribed bucchero imitations of writing tablets have been found at Chiusi and other sites; they are usually associated with burial assemblages which include many other bucchero imitations of everyday objects. ${ }^{67}$ These are in a 'tabula ansata' shape, with two notches on each long side so that the tablets could be tied together with string easily, mimicking a real wooden tablet. Looking beyond funerary contexts in Italy, evidence of votive writing exercises appears at the Etruscan sanctuary of Portonaccio near Veii in Latium. Large numbers of inscribed votives to Minerva, dating to the last quarter of the seventh century and the first half of the sixth century B.C., have been found, some of which are in the form of

63 Late seventh century B.C. The formula mi atianaia [...] alice venelusi means 'Atianaia gave me to Venel' - this is a gift from a woman to a man, not a dedicatory formula. Text: mi

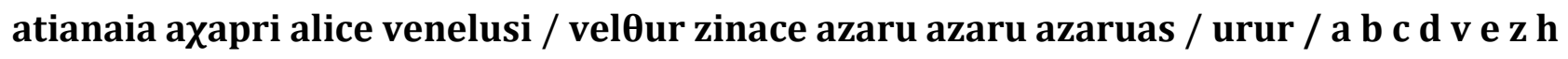

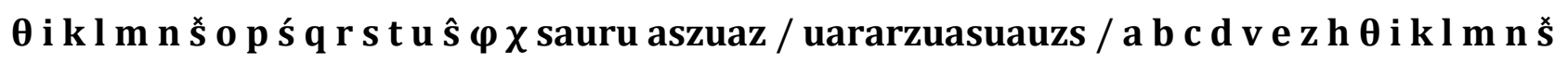
o p ś q r s t u ŝ $\varphi \chi$ ausazsuazusauazusa. ET Ve 3.1, 6.1, 9.1, 9.2; Buffa 1935: 241-2 \#841; Bundgård 1965: 32.

${ }^{64}$ Musei Vaticani 20349. ET Cr 9.1; Pandolfini and Prosdocimi 1990: 29-32; drawing available in Bundgård 1965.

65 Pandolfini and Prosdocimi 1990: 205-6.

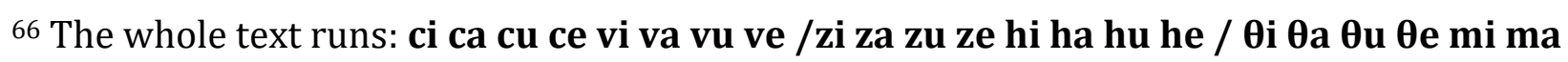

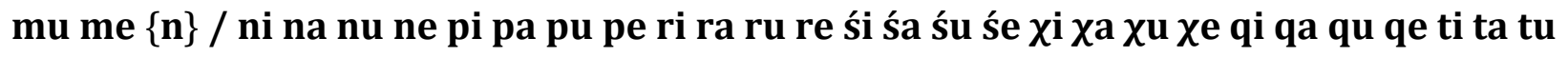
(t)e / a b c d e vzh $\boldsymbol{\theta}$ i k l m n s s o pśr s t u ŝ $\varphi \chi$

67 Buonamici 1932: 388 gives one possible inscribed example, although with an 'indecipherable' inscription; Bundgård 1965: 22-3; Cornell 1991: 24. 
abecedaria; these texts have suggested to scholars that the sanctuary was a centre for the acquisition of literacy. ${ }^{68}$

However, writing exercises in confirmed dedicatory contexts are rare. Scratched abecedaria on walls and small objects, such as those found at Pompeii (in both Oscan and Latin) and those found in the Greek-speaking world from the eighth century B.C. onwards, are usually interpreted as informal practice texts, and not as dedications. ${ }^{69}$ It is possible that some of the abecedaria which have been identified as educational texts may have had a votive or other ritual purpose which has not been recognised by modern editors. ${ }^{70}$

To find clear examples of the dedication of writing materials and exercises it is necessary to look outside Italy. A number of notable examples of this practice are found in the rock-cut sanctuaries of the Iberian Peninsula using both the Greek alphabet ${ }^{71}$ and the Iberian semi-syllabic script, which have been identified as alphabetic votives. ${ }^{72}$ While none of these abecedaria are as complex as the writing exercises shown on the Este-Baratella tablets or the Etruscan bucchero vessels, they suggest that abecedaria could be used in votive contexts. Abecedaria in magical texts (mainly dated much later) might also qualify as examples of the use of the power of writing to communicate with a deity. ${ }^{73}$

\footnotetext{
68 Maras 2015: 211.

${ }^{69}$ Latin, e.g. CIL 4.5472, 9272; Oscan: Crawford 2011: Pompei 74-81; Greek: West 2015. 70 Bucking 2012: 231-32.

71 Gomes 2013. Gomes dates this rock-cut alphabet to the first half of the fifth century B.C. ${ }^{72}$ Ferrer i Jané 2015. These abecedaria are dated to between the fourth and the first century B.C.
}

73 One is a lead alloy tablet found at Bath, probably written some time in the first four centuries A.D. In this case, the partial abecedarium $(<A B C D E F X>)$ was found in a votive context among curse tablets, and so the abecedarium may be understood as both a magical text and a votive simultaneously. Frere, Hassall, and Tomlin 1983: 336-7 with image; the editors speculate (fn 6) that the partial abecedarium may even be a coded reference to cursing: ABC def(i)x(io). Tomlin 2002: 166-7 notes the overlap between votives and curse tablets. There are other examples of alphabetic texts being used as magical texts from across the Roman Empire, such as a wooden amulet in Coptic from sixth/seventh-century Egypt, though these are mostly found from the fourth century onwards and are unlikely to represent magical practices current in Italy at the period when the Venetic texts were written: Frankfurter 1994: 199-200; Bucking 2012: 233. Curse tablets and amulets in Italy do not 
A particularly important example of the dedication of learners' writing exercises is the cult of Zeus Semios on Mount Hymettos near Athens. ${ }^{74}$ At this sanctuary site, which consists of a deep hollow about 1.5 kilometres from the peak, many small votive potsherds were dedicated. Two examples name the deity as Zeus Semios ('Zeus of the Signs'). ${ }^{75}$ Most of the other sherds (c. 160) are inscribed with partial abecedaria, usually three or four letters long. In general, the appearance of the texts suggests inexperienced writers; ${ }^{76}$ it is not clear whether they were purpose-made for dedication, or whether they were real writing exercises which were ceremonially discarded by their authors. The ostraka which bear the inscriptions are worthless in themselves, and several scholars have suggested that the writing itself is the key factor in creating a relationship with the deity. ${ }^{77}$ Whatever the exact motivation of the dedicators, it has been argued that these dedicatory texts speak to the exceptional relationship that archaic Athens had with literacy, particularly during the period when writing was still a rare skill in the region. ${ }^{78}$ However, as we have seen, not all votive practices connected to learning to write exist in societies where writing is a new technology, and it may be that these texts are later than they at first appear. ${ }^{79}$

feature voces magicae, alphabets or other similar features before the imperial period: McDonald 2015: 133-49.

74 Langdon 1976.

75 Langdon 1976: 3. Usually understood as a weather god, cf. the possible reference to this site at Pausanias, Description of Greece (Paus. 1.32.2), which refers to altars of Zeus Ombrios ('of rain') on Hymettos, and an altar of Zeus Semeleos ('sign-giving') on the nearby mountain of Parnes.

76 Two joining sherds, bearing a well-executed and poorly-executed abecedarium respectively, suggest the texts of a teacher and student. Langdon 1976: 17.

77 Langdon 1976: 46; Henrichs 2003: 51; Keegan 2014: 96; Woodard 2014: 266.

78 Langdon 1976: 46; Várhelyi 1996: 34-6; Henrichs 2003: 52 in particular emphasises that this practice is found nowhere else in the ancient world.

${ }^{79}$ The argument that these dedications to Zeus Semios only took place just after writing was introduced to Athens runs into chronological problems. The letter $<\mathrm{H}>$ is clearly used as a vowel in the epithet 'Semios', and the use of eta as a vowel in Athens is usually dated to the adoption of the Ionic spelling system around 403 B.C. (with variation in spelling either side of this date). The shapes of the letters lambda and sigma also suggest a date later than the seventh century. While it may be tempting to date these texts to the earliest stages of 
As this survey shows, there are no exact equivalents of the Venetic dedications to Reitia elsewhere in the Mediterranean. Although abecedaria, writing exercises and writing implements appear in burial and dedicatory contexts beyond the Veneto, it is only at Este that we seem to get such expensively and deliberately produced replicas of writing tablets. This is a localised dedicatory practice which, nevertheless, we can see as part of a wider Mediterranean context in which writing, including learning to write, could be the focus of votive activity. It is plausible that Venetic practices included the dedication of wooden writing tablets as non-purpose-made votives, similar to some of the ceramic examples found elsewhere, and that purpose-made bronze tablets were the most expensive extreme of a more varied and accessible set of votive practices. It is also possible communities elsewhere in Italy were dedicating real writing tablets made of wood and wax. The difference between the various elites of Italy was not always the kind of written texts which they produced, but the materials on which they produced them, with profound effects for the archaeological record see, for example, the vast differences in the preservation of written laws in different areas. ${ }^{80}$ It is possible, therefore, that writing tools made of wood and wax were dedicated both and Este and elsewhere. Perhaps the people of Este were unusual not in dedicating writing materials, but in their extensive use of bronze for categories of votives which elsewhere were made of materials such as ceramic (cf. the writing exercises at Caere, bucchero 'writing tablets' at Chiusi, and anatomical votives at many sites) or wood.

\section{EVIDENCE FOR ELEMENTARY EDUCATION IN ITALY}

\section{Evidence for writing exercises}

The interpretation of the votive dedications to Reitia in Part III relies, in part, on the texts on the bronze tablets being recognisable copies of the writing exercises completed by learners during their acquisition of literacy, or model exercises written by teachers. To judge the plausibility of this claim, we need to turn to comparative evidence from elsewhere in the

Athenian literacy, it is therefore possible that these texts belong to the fifth century or later; or, alternatively, some of these texts were written by people who were not from Athens. Many thanks to Philippa Steele.

${ }^{80}$ For example, Locri was famous for its written law code (Strabo 6.1.8; Diod. Sic. 12.20-1) but this region has much less epigraphic evidence for legal writing than other areas, presumably because the laws were not written on stone or bronze. 
ancient world. The few existing descriptions of the acquisition of basic literacy in Greek and Roman literature do not, in general, go into much detail about teaching techniques. As part of an extended metaphor, Plato describes schoolchildren of the fourth century tracing letters written faintly by their teachers (Prt. 326d) and progressing from learning their letters to reading works of poetry (325e); this process typically happened in childhood (326c). ${ }^{81}$ Elsewhere, Plato's Socrates indicates that in Greek education the letters were learned first, and then combined into syllables (Tht. 202e-204a). Dionysius of Halicarnassus, writing in the time of Augustus, also describes the progression from letters to syllables to words (Comp. 25).

The evidence from Italy is limited, and there is little information about how people learned to write before the Augustan period. ${ }^{82}$ In the first century A.D., Quintilian, drawing on Greek education, reiterates the idea that children should trace letters with their pen (Inst. 1.1.27). He mentions in addition the benefit of teaching the alphabet in a scrambled order, so that students have to recognise the shapes and not just the sequence (1.1.27). ${ }^{83}$ It is possible that this practice is found in the Roman alphabet on tablet Es 27, if Prosdocimi's reconstruction is correct, and that the scrambling on this tablet is mainly educational rather than magical. Like Plato, Quintilian also emphasises the importance of the syllable - he says that every syllable must be learned individually, and that when children start to read words they should be encouraged to break them into syllables (1.1.30-3). In On Order, Augustine describes the sequence of education, from learning letters to learning syllables, as

${ }^{81}$ Quintilian implies that the usual start of elementary education in Greece was at age seven (Inst. 1.1.15).

82 Although we have some scattered information about learning methods in Republican Italy, debate continues about where this learning took place. A few texts mention schools, but is not clear how organised or widespread these were. Livy (3.44.4-6) describes the abduction (c. 450 B.C.) of Verginia as she was walking to school one morning in the forum; this is often considered implausibly early for a school in Rome. In his Roman Questions, Plutarch states that the first school at Rome was opened by the freedman Spurius Carvilius in c. 230 B.C. (Quaest. Rom. 59). Plautus' play The Merchant mentions children going to school to learn their letters at seven years old (Plaut., Merc. 289-304), and the speaker jokes that he already knows three letters: A M O (I love). The existence of schools in the Hellenistic world, which are attested in papyri and inscriptions, is less controversial.

${ }^{83}$ Examples of this practice can also be seen in, e.g., CIL 4.5472, 9272 (Pompeii, first century A.D.). See Milnor 2014: 25 for more on this kind of 'recreational literacy' in the Roman world. 
immutable. ${ }^{84}$ This system is also implied in the description of the school day in the Colloquia Monacensia-Einsidlensia. ${ }^{85}$ These passages give us a basic framework for how Greek and Roman elementary education might have progressed - from letters to syllables to poetry or other texts; they all emphasise that understanding different syllable structures was an important stage of the learning process. They do not, however, give us much detail about the exercises used at each stage - fortunately, extant epigraphic and papyrological evidence complements these accounts.

The many surviving school exercises from different educational levels show remarkable consistency across time and space. ${ }^{86}$ Some of the most complete sets of basic literacy exercises from the ancient world are Hellenistic examples roughly contemporary with the Venetic dedications to Reitia. ${ }^{87}$ For example, the text known as the 'livre d'écolier' ('school-child's book') is a series of papyrus fragments purchased in 1935,88 dated to the final quarter of the third century B.C. based on the palaeography. ${ }^{89}$ This book, and other comparable papyrological texts, gives us a much more complete idea of the system of exercises Plato and Quintilian had in mind when describing the learning process. ${ }^{90}$ It also provides a useful point of reference for the Venetic dedications as examples of learners' texts. The text of the 'livre d'écolier' consists of a series of writing exercises, written out by a teacher

${ }^{84}$ August., De ordine 2.7.24.

85 'Meanwhile, as the teacher orders, the little ones get up to [practise] letters, and one of the bigger [pupils] gave [Gk: told] them syllables.' Dickey 2012: 107. The same text mentions ruling lines on the writing tablet before beginning (Dickey 2012: 107), perhaps providing a parallel to the grid on the Venetic tablets.

86 Cribiore 1996: 27-33; Morgan 1998: 3; Dickey's recent editions of colloquia represent another kind of learning (foreign language acquisition, mainly through word lists, phrases, stories and grammatical exercises, in facing-column format), which is not the focus of this article: Dickey 2012; Dickey 2015; Dickey 2016; also Morgan 1998: 165-9.

87 Dating of these kinds of texts is usually based on handwriting, however, and is problematic: Harrauer and Sijpesteijn 1985: 13.

88 Provenance given by the dealer as Fayoum. Guéraud and Jouguet 1938: xi; Morgan 1998: 164.

${ }^{89}$ Guéraud and Jouguet 1938: xiv.

90 Joyal, McDougall, and Yardley 2009: 124-8. Other examples from later periods include texts in Coptic (Bucking 2006); and Latin (García y García 2005: 39). 
as a pedagogical aid. The papyrus gives a series of tables, each building on the skills learned in the previous section. The first table is a list of open syllables, constructed by adding each consonant to each vowel in turn. This section is fragmentary but the pattern is clear from the remains of two of the columns: ${ }^{91}$

1.

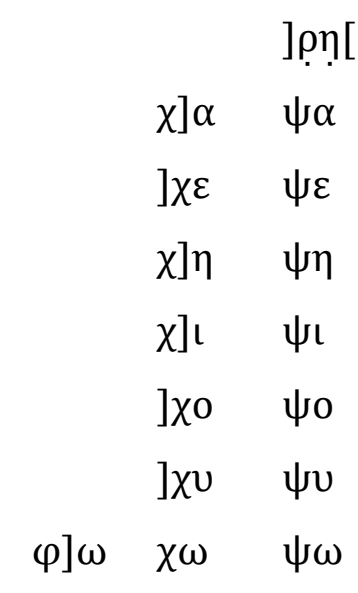

The second table introduces closed syllables ending in $<v>$ and then closed syllables beginning with consonant clusters and ending in $<\sigma>:{ }^{92}$

$[\alpha \nu \beta \alpha \nu \gamma \alpha \nu \delta \alpha] \nu \zeta \alpha \nu \theta \alpha v[\kappa \alpha \nu \mu \alpha \nu v \alpha v] \xi \alpha \nu \pi \alpha v \rho \alpha v[\sigma \alpha \nu \tau \alpha \nu \varphi \alpha v \chi \alpha v] \psi \alpha \nu$

10. $\varepsilon v[\beta \varepsilon \nu \gamma \varepsilon \nu \delta \varepsilon] \nu \zeta \varepsilon \nu \theta \varepsilon v[\kappa \varepsilon \nu \mu \varepsilon v \nu \varepsilon v] \xi \varepsilon v \pi \varepsilon \nu \rho \varepsilon v \sigma \varepsilon[v] \tau[\varepsilon v] \varphi[\varepsilon v \chi \varepsilon] \nu \psi \varepsilon v$

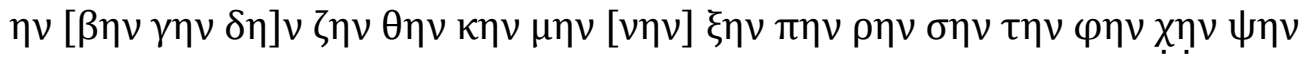

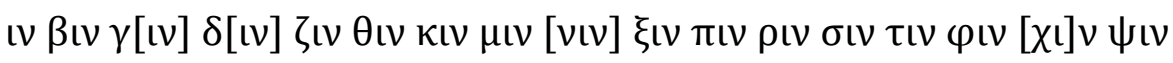

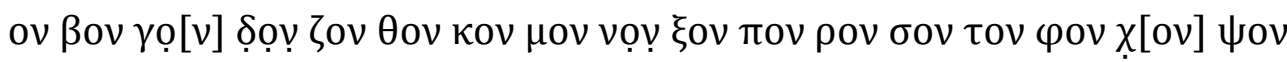

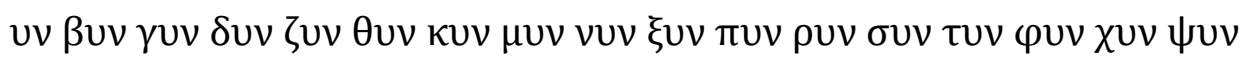

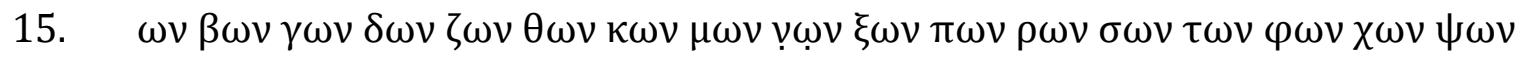

$[\ldots]$

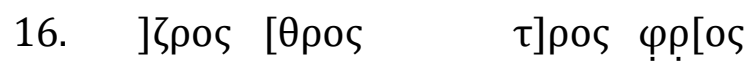

]

] $\rho \omega \varsigma$ $\theta \rho[\omega \varsigma \quad] \tau \rho \omega \varsigma \varphi \rho \omega[\varsigma$

The text then goes on to give words of one syllable with several consonant clusters (some of which are nonsense words or onomatopoeia), followed by names of two, three, four and five syllables. The use of these single-syllable words is paralleled in educational texts elsewhere, such as a (possible) teacher's model and student's copy of the same exercise on an ostraka

\footnotetext{
91 Guéraud and Jouguet 1938: 1.

92 Guéraud and Jouguet 1938: 2. Guéraud and Jouguet also give some comparisons to similar exercises found in other papyri; more examples can be found in Johnson 2011; see Harrauer and Sijpesteijn 1985: 27-34 for much later examples (1st - 7th century A.D.).
} 
from southern Gaul in the third or second century B.C., which includes a partial abecedaria and the word $\kappa v \alpha \xi$, which is also found in the 'livre d'écolier' one-syllable word list. ${ }^{93}$ The book's polysyllabic words and names are divided into syllables using punctuation. For

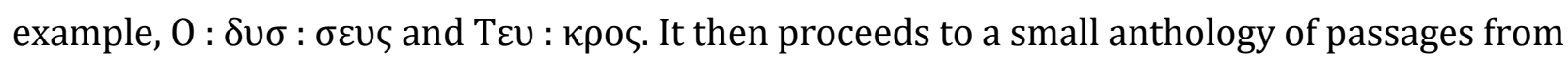
poetry, including excerpts from Euripides, the Odyssey, new comedy, a selection of epigrams, and some word lists. ${ }^{94}$

The pedagogy of Greek elementary education comes through clearly in this text and others like it. ${ }^{95}$ The book may have begun with an alphabet or alphabets, but if it existed this section is now lost. However, we can see that the next stage after the acquisition of the alphabet is focused on the syllable. The syllable structures are made progressively more complex: teaching starts with the mechanical creation of every possible open syllable, then a few types of simple closed syllables, progressing towards syllables with multiple consonant clusters. In many cases, these syllables were ones which never or rarely occurred in real words. ${ }^{96}$ Only when these different types of syllable were mastered did the student move on to multiple syllable words, in which the different syllables were clearly separated out by punctuation. Even in the first extract of the poetic anthology, the syllables are punctuated for the student. For example: 97

120. $\varphi \mathrm{\iota}: \lambda \mathrm{o}: \tau \mathrm{\iota}: \mu \mathrm{\iota}: \alpha \varsigma \pi \alpha \mathrm{s}: \mu \eta: \sigma \mathrm{v}: \gamma \varepsilon:$

$$
\begin{aligned}
& \alpha: \delta \iota: \text { коऽ : } \eta \theta \varepsilon: \text { о }
\end{aligned}
$$

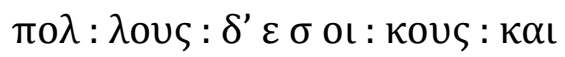

$$
\begin{aligned}
& \pi 0: \lambda \varepsilon เ \varsigma: \varepsilon \cup: \delta \alpha \iota: \mu o: \nu \alpha \varsigma \text { : }
\end{aligned}
$$

We see the same focus on syllable structure in the Venetic dedications to Reitia. These exercises do not cover the same section of the learning process as the Greek-focused 'livre d'écolier', but show a similar pedagogical framework. The Reitia inscriptions show that the next stage after learning the alphabet itself was to think about syllable structure and

\footnotetext{
93 Bats 1988: 127; Fournet 2000, who dates it to the third century or the first quarter of the second century.

${ }^{94}$ Guéraud and Jouguet 1938: xv. See also Dickey (2012) for the colloquia, which show how short phrases and word lists were combined into stories as part of foreign-language learning. 95 Cribiore 1996: 31.

${ }^{96}$ Cribiore 2001: 173.

97 Guéraud and Jouguet 1938: 14. The text is Euripides' Phoenician Women (Eur., Phoen. 5324).
} 
consonant clusters, rather than progressing straight from the alphabet to words. In the case of the Venetic writing system, there was a specific set of clusters which had to be rote-learned for the purposes of syllabic punctuation, and as a result the progression of the exercises is not exactly the same as those found in Egypt. Nevertheless, the similar focus on syllable structure and consonant clusters in both the Venetic dedications and a Greek learning aid suggests that the dedications are accurate copies of real writing exercises of the period.

Abecedaria and repeated letters are also commonly used in Greek learners' exercises. For example, we find the use of repeated letters in a papyrus example from the fifth or sixth century A.D., where the student has written $\alpha \boldsymbol{\alpha} \alpha \varepsilon \lambda \eta \eta \eta \boldsymbol{\eta} \boldsymbol{\lambda} \varepsilon \lambda \varepsilon \lambda \rho \boldsymbol{\rho} \rho \boldsymbol{\rho} \rho{ }^{98}$ An even closer parallel is found, both in form and in chronology, in some examples from Greek settlements on the Black Sea from the fifth to the third centuries B.C., which show abecedaria, or just the repeated letters $\boldsymbol{\alpha} \boldsymbol{\beta} \boldsymbol{\gamma}$, enclosed in a grid just like in the Venetic tablets. ${ }^{99}$ This suggests that some teachers may have provided grids to help very early learners to write clearly. Evidence from Egypt shows that wooden or waxed tablets, which would be passed around easily, were a common material for teachers' models, while students used ostraka or offcuts of papyrus; ${ }^{100}$ one could argue, therefore, that the bronze Venetic tablets mimic teachers' models rather than student exercises.

At a slightly earlier period to both the Venetic examples and the Egyptian 'livre d'écolier', there is evidence of writing exercises in Etruria. Part III, above, mentioned the syllable exercises which appear on bucchero objects, such as the flask from Caere with its model alphabet and open syllable sequence. None of the Etruscan lists of syllables are as complex as the exercises in the papyri or in the Venetic dedications. ${ }^{101}$ These examples also cluster around the seventh and sixth centuries B.C., predating those from Este. Nevertheless, these examples show that writing exercises based on systematic series of syllables were used in Italy, and that elementary education at Este could plausibly be built on this system.

\footnotetext{
98 P.Vindob. G 26011a. Harrauer and Sijpesteijn 1985: 34.

99 Dana 2009: 77-9.

100 Cribiore 1996: 125; Dana 2009: 72 argues that ostraka were chosen not just because of cost, but because the rough surface encouraged simple, clear letters, whereas wooden boards were used to encourage cursive; however, the very low rates of preservation of wooden tablets makes it hard to confirm this pattern.

101 Bagnasco Gianni 2005.
} 
This is not to say that Venetic systems of education were directly reliant on the Greek or Etruscan worlds. As already noted, the Venetic writing system had peculiarities which necessitated certain types of exercises for learners, including the retention of exercises for learning syllabic punctuation for several centuries longer than in the Etruscan world. The texts also show signs of continued adaptation in the loss of dead letters and the changes to the alphabetical order in the exercises. However, these comparisons help us to put Venetic elementary education into its Italian and Mediterranean context as part of a wider culture of pedagogical practices. ${ }^{102}$ It is plausible that the teaching of literacy in the Venetic world followed systems that were not dissimilar to those found in the Hellenistic world and Etruria, and that, as with the Venetic alphabet itself, there was ongoing interaction between these systems rather than a single point of transmission.

\section{Who learned to write and why?}

In past scholarship, it has often been suggested that the most plausible explanation for the number of dedicatory writing implements at Este-Baratella is the presence of an important scribal school at Este, either at the sanctuary or nearby. ${ }^{103}$ However, the large number of women's names in the nominative, which implies that women were frequent dedicators of these kinds of texts, makes scribal training less likely to be the only reason for these dedications. ${ }^{104}$ Most of the texts have a named dedicator, although in some cases the dedicator's name is omitted on purpose or missing through damage. A few names cannot be

102 Pandolfini and Prosdocimi 1990: 184-5, in contrast, state that the entire system (of punctuation and education) most likely radiated from one (Etruscan) site.

103 Pellegrini and Prosdocimi 1967: 104; Lejeune 1971; Wachter 1986: 112; Prosdocimi 1990: 269-70; Lomas 2008; for the idea that there was a scribal school at Portonaccio, see: Maras 2012.

104 We know very little about scribal training in the Mediterranean in this period; it is not clear whether it took place in tandem with other elementary education: Morgan 1998: 32. Most scribes in the ancient world are unnamed, and so it is not necessarily true that they were exclusively male. However, I am not aware of any evidence of named female scribes in Classical antiquity, on gravestones naming professions, on papyri which name scribes or translators, or elsewhere. It is perfectly possible that literate women worked as scribes, or offered their services as readers and writers for pay in other ways (e.g. as pedagogues and tutors, for which there is better evidence). 
reliably identified as male or female. Other names have damage which prevents us from seeing the morphological ending and therefore the gender of the name. Despite these problems, we can see that women are found as dedicators for three of the extant writing tablets (versus eight men) and that only women are attested as dedicators of styluses.

\begin{tabular}{|l|c|c|c|c|}
\hline & Male & Female & ? or not stated & Total \\
\hline $\begin{array}{l}\text { Bronze tablet } \\
\text { (dedicator) }\end{array}$ & 8 & 3 & 12 & 23 \\
\hline $\begin{array}{l}\text { Bronze tablet } \\
\text { (beneficiary) }\end{array}$ & 2 & 0 & 22 & 24 \\
\hline Stylus (dedicator) & 0 & 22 & 3 & 25 \\
\hline Stylus (beneficiary) & 1 & 5 & 19 & 25 \\
\hline Other (dedicator) & 10 & 0 & 4 & 14 \\
\hline
\end{tabular}

Table 1. Male and female names in the dedications to Reitia.

Some texts also have additional named persons who are 'beneficiaries' of the dedication. The only example of this practice in the writing tablets shows a male dedicator making a dedication to at least one male beneficiary (probably two). For the styluses, all but one of the beneficiaries are also female: the exception is Es 45, where a woman Egetora makes the dedication .<a>.i.mo.i. ke lo.u.derobo.s. 'for Aimos and (their) children'.

The association between women and writing materials is particularly strong, since other kinds of objects dedicated to Reitia do not name women as their dedicators or beneficiaries. Most of the other inscribed dedications at Este, as mentioned in the introduction, are stone pedestals topped with bronze statues, probably mainly equestrian statues. All of these are dedicated by men, where a dedicator is named. The handful of inscribed dedications of other kinds (a bronze kantharos and two freestanding stones) are also dedicated by men. This sanctuary does not just show an association of women with Reitia - since Reitia had other strings to her bow - but an association of women with the specific aspect of the goddess relating to writing and learning to write. We do not know the gender of the dedicators of the uninscribed votives, such as the anatomical votives, but the majority of the statuettes, for example, show female figures, which may suggest women's involvement in other aspects of the sanctuary as well. Given this evidence, it is misleading to try to make scribal training the main focus of the dedicatory activity at Este-Baratella. This approach plays 
down the other facets of the goddess, as well as reducing the role of women as active participants in religious activity at the sanctuary.

The effect of this focus on scribal training has been to minimise elite Venetic women's participation in literacy and the epigraphic habit. ${ }^{105}$ Instead, women should be re-centred in the analysis of votive practices at Este, both in their role as dedicators and in their association with the educational aspect of Reitia. Class is just as important as gender in understanding their role. As Cribiore has emphasised, 'wealth and social status were even more determinant education factors for females than for males. A disproportionately high percentage of girls who completed the first educational level were elite, as compared to the more varied social backgrounds of male students.' ${ }^{106}$ As argued above, the dedication of bronze votives was an elite activity, and may be the visible remains of a wider practice which included the dedication of wooden writing tools; the association of elite women with this practice fits with Cribiore's evidence.

At Este, a unusually high proportion of the surviving funerary monuments commemorate women, though they were still in the minority. ${ }^{107}$ Although these monuments were not written by the women that they memorialise, this contributes to our picture of a culture in which women were highly involved in the epigraphic activity of the city, in contrast to many other regions. ${ }^{108}$ The combination of women's visibility in dedications which explicitly reference learning to write and their frequent commemoration on gravestones also makes Este qualitatively different from areas of Italy where women's names are commonly found on gravestones but rarely in other kinds of written text. In these areas - such as the Paelignian-speaking area around Corfinium and Sulmo - it is easier to put the visibility of women down to the habits of elite display among their male relatives, who would have had primary responsibility for the burial. ${ }^{109}$ It is not easy to make a similar case for women's

105 See Milnor 2014: 200-1 for the tendency for scholarship to minimise female literacy. 106 Cribiore 2001: 4; also Hemelrijk 1999: passim.

10726 per cent female, 41 per cent male, 2 per cent both, 31 per cent damaged or uncertain. McDonald forthcoming.

108 Lomas 2009: 13.

109 The funerary inscriptions from Corfinium (Crawford 2011: Corfinium 6-35) and Sulmo (Crawford 2011: Sulmo 4-11, 13-23) are another example of the localised visibility of women in the epigraphic record. At Corfinium, eight monuments are to women, twenty-one to men, and one to a man and a woman; at Sulmo, eleven are to women and eight to men. Many of the 
participation in Reitia's cult: the role of dedicators in votive dedications is more participatory than the role of the deceased at a burial. I would argue that their involvement in dedicating writing tablets indicates that women did learn to write, and that their dedications commemorated either their skill or (perhaps) their aspirations. Este, like parts of Etruria, may therefore have been a culture in which basic literacy among the elite was not so dependent on gender as it was in Greece and Rome. ${ }^{110}$

The involvement of women in epigraphic culture has sometimes been treated as an incidental oddity, and perhaps a highly localised phenomenon peculiar to Este. Another approach, however, would be to look more broadly at literacy in the rest of first-millennium Italy, and to note that the Venetic dedications may be part of a wider network of evidence for women's writing. We should note, for example, that women and their daily activities are associated with writing from the earliest stages of alphabetic writing in Italy, particularly in Etruria. ${ }^{111}$ From as early as the eighth century, spools, spindle whorls and loom weights objects associated with textile production, and therefore with the economic activities of both elite and non-elite women - are found marked with Greek or Etruscan letters. ${ }^{112}$ Another nonelite example is the late second century Oscan/Latin bilingual inscription from Samnium, which shows two female tile-factory workers, probably slaves or freedwomen, using writing casually to inscribe short messages in the wet clay of a tile. ${ }^{113} \mathrm{~A}$ text on a small bucchero perfume vase which might be characterised as 'a short Etruscan poem', signed by a woman, has been found at Caere and dated to the end of the seventh century. ${ }^{114}$ There were strong

women commemorated are explicitly referred to as priestesses, which means that this corpus differs considerably from Este's.

110 For the mixed feelings that educated women provoked in the Roman world: Morgan 1998: 48; Hemelrijk 1999: 84-8.

111 Stoddart and Whitley 1988 argue that Etruscan literacy was strongly linked to the powerful elite, but there is an argument that it extended further into everyday life than they allow.

112 For example, the spindle whorl from tomb 21 at Vulci necropolis, end of the seventh century, with the inscription a e v z h. Bagnasco Gianni 2000: fig. 17; Maras 2015: 209; Maras notes that some scholars have nevertheless chosen to see these texts as produced entirely by men. See also Ambrosini 2000; Roth 2011.

113 Crawford 2011: Teruentum 25; Clackson 2012: 41.

114 Maras 2015: 210. 
links between the cultures of literacy in Etruria and the Veneto, and the participation of women in literacy may have been similar in the two regions.

More evidence exists for female participation in elementary education in the ancient world generally than is sometimes appreciated; the fact that many ancient authors were more interested in boys' education should not lead us to forget that in some places in the ancient world, women were regularly educated at elementary level. Cribiore cites an inscription from Xanthus, Lycia, in the second century A.D. which clearly mentions the availability of free education for both boys and girls - uptake from girls might have been lower, but the provision was available. ${ }^{115}$ Eight of the eighty-seven references to 'teachers' in the Egyptian papyri refer to women, although some of these may refer to people taking on apprentices rather than those teaching basic literacy specifically. ${ }^{116}$ The famous first-century A.D. mummy of Hermione Grammatike, now in Girton College, Cambridge, is perhaps another example of a woman being named as a teacher. ${ }^{117}$ The image of two girls on a fifth-century Attic kylix has also been used as evidence for Greek women attending school, although it is difficult to interpret this image. 118

Even in Roman Italy, where it is generally accepted that female literacy was much lower than male literacy, there is evidence that some non-elite women participated in education as both learners and teachers. A number of literary texts incidentally mention girls as pupils or readers. ${ }^{119}$ In Apuleius' Metamorphoses (Apul., Met. 9.17.2) one woman refers to another as a 'school-mate' or 'fellow-pupil' of hers. ${ }^{120}$ Six examples of female pedagogues are known from Rome (CIL 6.4459, 6331, 9754, 9758), one in Samnium (CIL 9.6325) and one in Africa (CIL 8.1506); ${ }^{121}$ one is also mentioned in the Oxyrhynchus papyri (P.Oxy. 50.3555). Pedagogues accompanied children to school, but also sat with them during lessons, helped them with their work, and set additional exercises - this was a job with low pay and social status, but some skill was involved.122 The inscriptional evidence reveals that this was a

\footnotetext{
115 Cribiore 2001: 74: SEG 30.1535.

116 Cribiore 2001: 46.

117 Cribiore 2001: 79.

118 Metropolitan Museum of Art 06.1021.167.

${ }^{119}$ Horace, Sat. 1.10.90-1; Martial, Ep. 3.69.7-8; 8.3.15-16; 9.68.1-2.

120 novi diligenter. areten meam condiscipulam memoras.

121 Horster 2011: 92.

122 Cribiore 2001: 47-9; Horster 2011: 93.
} 
position which could be held by free or freed women (free: 6.9754; freed: 6.6331; others not stated) at various ages, assuming that at their death these women had been pedagogues recently (6.9758 died aged 25; 8.1506 died in her seventies). The inscription CIL 6.9754 seems to record two (or more) sisters commemorating their two pedagogues, one male and one female. ${ }^{123}$

So, if the Venetic dedications are not necessarily the result of a scribal training school, can we associate them with any kind of education being provided outside the home? As shown above, writing exercises analogous with, though not identical to, those found on the dedication tablets at Este-Baratella are found in contexts elsewhere in the Mediterranean which suggest that they were part of semi-organised elementary education of elite people, often assumed to be children, particularly boys. It is plausible that a similar system of teaching literacy to small groups was also in use in the Veneto in approximately the fourth to the second centuries B.C. Teaching may have occurred at the Baratella site itself, but need not have done. The names on the dedications suggest that these groups may have included girls as well as boys, and perhaps also married women with children, if Es 45 refers to the dedicator's own husband and children. ${ }^{124}$ Although the Venetic sources only give direct evidence of elite dedicatory practices, it is possible that both men and women of other social groups learned to write and made dedications on perishable materials.

\section{CONCLUSIONS}

The dedications to Reitia at Este-Baratella are a unique form of dedicatory practice, whether we interpret these dedications as celebrations of the end of the process of acquiring literacy, markers of educational milestones or aspirations to learn. They also give a rare insight into how basic literacy was taught in ancient Italy from the fourth to the second century B.C., both in Venetic and Latin. However, as evidence of both dedicatory and educational practices, the

\footnotetext{
${ }^{123}$ C(aius) Sulpicius C(ai) l(ibertus) / Venustus / Sulpicia C(ai) l(iberta) Ammia / Sulpiciae C(ai) f(iliae) Galbillae / paedagogis suis. CIL 6.9754. 'Caius Sulpicius Venustus, freedman of Caius, and Sulpicia Ammia, freedwoman of Caius. (The) Sulpicia Galbilla (sisters), daughters of Caius, (made this) for their pedagogues.'

124 If this interpretation is correct, it creates quite a different impression than Hemelrijk's description of the division of Roman women's education into pre- and post-marriage periods, outside and inside the home respectively. Hemelrijk 1999: 21.
} 
dedications to Reitia need to be seen in their wider Italian and Mediterranean context. As dedications, these texts are perhaps best seen as an unusually elaborate form of a practice found across many different languages and cultures in the ancient world. Examples from Greece, Iberia and elsewhere show that votive abecedaria could exist without more complex writing exercises; practices in Etruria are probably the closest match for the inscriptions at Este-Baratella. The Venetic evidence also provides a helpful counter-example to the idea that such dedications only occurred in Greece, or only in areas which had recently adopted alphabetic writing.

As educational texts, the Este-Baratella tablets are easiest to understand when seen as part of a wider network of individuals acquiring literacy across the Mediterranean, including in Etruria, Greece and Rome. By making these comparisons, we can build up a wider picture of the exercises that were used at the different stages of the acquisition of literacy, and how these exercises were adapted to the needs of different writing systems. On the whole, ancient education devoted considerable time to understanding the syllable and different syllabic structures, rather than progressing straight from letters to words. This was particularly important in writing systems like Venetic and Etruscan, where the syllable formed the basis of the punctuation system, but is also seen in Greek and Roman education.

Finally, the role of women in the production of these dedications should not be underestimated. Like any purpose-made dedication, the bronzes were probably not produced by the dedicators named on them; but those dedicators, whether male or female, did decide to commission a dedication in the form of a writing implement, and may have had input into the text. Although past scholarship has sometimes tried to minimise the roles of women, based on an assumption that their participation in literacy in ancient Italy must have been very low, these dedications provide evidence that some elite women at Este-Baratella were literate - or, at the very least, were active participants in a dedicatory practice which celebrated elementary literacy. The epigraphic habit of Este appears to be unique in some respects, and so it is very difficult to say what implications these texts have for female literacy in the rest of the Veneto or the rest of Italy. However, the Este-Baratella dedications do fit into a wider picture of women's engagement with literacy and education in Italy, which stretches back to the earliest stages of alphabetic writing.

\section{University of Exeter}

k.l.mcdonald@exeter.ac.uk 


\section{BIBLIOGRAPHY}

ET = Meiser, G., and Rix, H. 2014: Etruskische Texte: Editio Minor, Revised ed., Hamburg.

Ambrosini, L. 2000: 'I pesi da telaio con iscrizioni etrusche', Scienze dell'Antichità 10, 139-62. Bagnasco Gianni, G. 2000: L'etrusco dalla A alla 8. L'acquisizione della scrittura da parte degli etruschi, Milan.

Bagnasco Gianni, G. 2005: 'Iscrizioni con sillabe ripetute: un inedito da Tarquinia', ACME 58, 77-88.

Balista, C. and Ruta Serafini, A. 1992: 'Este preromana. Nuovi dati sulle necropolis', in Tosi $1992,109-23$.

Bats, M. 1988: 'La logique de l'écriture d’une société à l'autre en Gaule méridionale protohistorique', Revue archéologique de Narbonnaise 21, 121-48.

Beeler, M. S. 1949: The Venetic Language, Berkeley and Los Angeles.

Bloomer, W. M. 2011: The School of Rome: Latin Studies and the Origins of Liberal Education, Berkeley.

Bodel, J. 2009: '“Sacred dedications”: a problem of definitions', in J. Bodel and M. Kajava (eds), Dediche sacre nel mondo greco-romano. Diffusione, funzioni, tipologie, Rome, 17-30.

Bonfante, G. and Bonfante, L. 2002: The Etruscan Language: An Introduction, 2nd edn, Manchester and New York.

Bowman, A. K. and Woolf, G. 1994: Literacy and Power in the Ancient World, Cambridge.

Bucking, S. 2006: 'A Sahidic Coptic manuscript in the private collection of Lloyd E. Cotsen (P. Cotsen 1) and the limits of papyrological interpretation', Journal of Coptic Studies 8, 5578.

Bucking, S. 2012: 'Towards an archaeology of bilingualism: on the study of Greek-Coptic education in late antique Egypt', in A. Mullen and P. James (eds), Multilingualism in the Graeco-Roman Worlds, 225-64.

Buffa, M. 1935: Nuova raccolta di iscrizioni etrusche, Florence.

Bundgård, J. 1965: 'Why did the art of writing spread to the West? Reflexions on the alphabet of Marsiliana', Analecta Romana Instituti Danici 3, 11-72.

Buonamici, G. 1932: Epigrafia etrusca, Florence.

Capuis, L. and Chieco Bianchi, A. M. 1992: 'Este preromana. Vita e cultura.', in Tosi 1992, 41108. 
Clackson, J. 2012: 'Language maintenance and language shift in the Mediterranean world during the Roman Empire', in A. Mullen and P. James (eds), Multilingualism in the Graeco-Roman Worlds, Cambridge, 36-57.

Conway, R. S. 1916: 'Some votive offerings to the Venetic goddess Rehtia', Journal of the Royal Anthropological Institute of Great Britain and Ireland 46, 221-9.

Cornell, T. 1991: 'The tyranny of the evidence: a discussion of the possible uses of literacy in Etruria and Latium in the archaic age', in J. H. Humphrey (ed.), Literacy in the Roman World, Journal of Roman Archaeology Supplementary Series 3, Ann Arbor, 7-33.

Crawford, M. H. 2011: Imagines Italicae: A Corpus of Italic Inscriptions, 3 vols, London.

Cribiore, R. 1996: Writing, Teachers, and Students in Graeco-Roman Egypt, Atlanta.

Cribiore, R. 2001: Gymnastics of the Mind: Greek Education in Hellenistic and Roman Egypt, Princeton.

Cristofani, M. 1969: 'Appunti di epigrafia etrusca arcaica', Annali della Scuola Normale Superiore di Pisa 38, 99-113.

Dana, M. 2009: 'Alphabets et exercices scolaires dans deux cités du Pont ouest: Istros et Tyras', Zeitschrift für Papyrologie und Epigraphik 171, 71-82.

Dickey, E. 2012: The Colloquia of the Hermeneumata Pseudodositheana. Vol. 1, Cambridge.

Dickey, E. 2015: The Colloquia of the Hermeneumata Pseudodositheana. Vol. 2, Cambridge.

Dickey, E. 2016: Learning Latin the Ancient Way: Latin Textbooks from the Ancient World, Cambridge.

Ferrer i Jané, J. 2015: 'L'escriptura ibèrica a la Cerdanya: els abecedaris rupestres', ERA, Revista cerdana de Recerca, 37-48.

Fogolari, G. and Prosdocimi, A. L. 1988: I Veneti antichi. Lingua e cultura, Padua.

Fournet, J.-L. 2000: 'Au sujet du plus ancien chalinos scolaire: chalinoi et vers alphabétiques grecs', Revue de Philologie 74, 61-82.

Frankfurter, D. 1994: 'The magic of writing and the writing of magic: the power of the word in Egyptian and Greek traditions', Helios 21, 189-221.

Frere, S. S., Hassall, M. W. C. and Tomlin, R. S. 0. 1983: 'Roman Britain in 1982', Britannia 14, 279-356.

García y García, L. 2005: Pupils, Teachers and Schools in Pompeii: Childhood, Youth and Culture in the Roman Era, trans. A. M. Poli, Rome.

Ghirardini, G. 1888a: 'Este. Intorno alle antichità scoperte nel fondo Baratela', Notizie degli scavi di antichità, 3-42. 
Ghirardini, G. 1888b: 'Este. Intorno alle antichità scoperte nel fondo Baratela. Parte II:

Antichità figurate', Notizie degli scavi di antichità, 72-127.

Glinister, F. 2006: 'Reconsidering “religious Romanization"', in C. E. Schultz and P. B. Harvey Jr (eds), Religion in Republican Italy, Cambridge, 10-33.

Gomes, M. V. 2013: 'O abecedário rupestre, proto-histórico, do Vale da Casa (Vila Nova de Foz Côa)', Revista da Faculdade de Letras Ciências e Técnicas do Património 12, 69-85.

Gow, A. S. F. 1956: 'Phanias: notes and queries', Classical Quarterly 6, 231-36.

Graham, E.-J. 2014: 'Infant votives and swaddling in Hellenistic Italy', in M. Carroll and E.-J. Graham (eds), Infant Health and Death in Roman Italy and Beyond, Journal of Roman Archaeology Supplementary Series 96, Portsmouth, RI, 23-46.

Graham, E.-J. 2017: 'Partible humans and permeable gods: anatomical votives and personhood in the sanctuaries of central Italy', in J. Draycott and E.-J. Graham (eds), Bodies of Evidence: Ancient Anatomical Votives Past, Present and Future, Oxford and New York, $45-62$.

Graham, E.-J. and Draycott, J. 2017: 'Introduction: debating the anatomical votive', in J. Draycott and E.-J. Graham (eds), Bodies of Evidence: Ancient Anatomical Votives Past, Present and Future, Oxford and New York, 1-19.

Guéraud, O. and Jouguet, P. 1938: Un livre d'écolier du IIIe siècle avant J-C, Cairo.

Haas, O. 1952: 'Zur Deutung der venetischen Inschriften', Die Sprache 2, 222-40.

Habinek, T. 2011: 'Situating literacy at Rome', in W. A. Johnson and H. N. Parker (eds), Ancient Literacies: The Culture of Reading in Greece and Rome, Oxford, 114-40.

Harrauer, H. and Sijpesteijn, P. J. 1985: Neue Texte aus dem Antiken Unterricht, Vienna. Harris, W. 1989: Ancient Literacy, Cambridge MA.

Hemelrijk, E. A. 1999: Matrona Docta: Educated Women in the Roman Élite from Cornelia to Julia Domna, London and New York.

Henrichs, A. 2003: 'Writing religion: inscribed texts, ritual authority and the religious discourse of the polis', in H. Yunis (ed.), Written Texts and the Rise of Literate Culture in Ancient Greece, Cambridge, 38-58.

Horster, M. 2011: 'Primary education', in M. Peachin (ed.), The Oxford Handbook of Social Relations in the Roman World, Oxford, 84-100.

Hughes, J. 2017: "Souvenirs of the self": personal belongings as votive offerings in ancient religion', Religion in the Roman Empire 3, 181-201.

Johnson, W. A. 2011: 'Teaching the children how to read: the syllabary', Classical Journal 106, 445-63. 
Joyal, M., McDougall, I. and Yardley, J. C. 2009: Greek and Roman Education: A Sourcebook, London and New York.

Keegan, P. 2014: Graffiti in Antiquity, London and New York.

Langdon, M. K. 1976: A Sanctuary of Zeus on Mount Hymettos. Hesperia Supplements 16, Athens.

Langslow, D. 2002: 'Approaching bilingualism in corpus languages', in J. N. Adams, M. Janse, and S. Swain (eds), Bilingualism in Ancient Society: Language Contact and the Written Word, Oxford, 23-51.

Langslow, D. 2012: 'Integration, identity and language shift: strengths and weaknesses of the "linguistic" evidence', in S. T. Roselaar (ed.), Processes of Integration and Identity Formation in the Roman Republic, Leiden, 289-309.

Lejeune, M. 1950: 'La "liste des groupes de consonnes" dans les "tablettes alphabétiques" d'Este', Bulletin de la Société de Linguistique de Paris 46, xiv-xv.

Lejeune, M. 1952: 'Problèmes de philologie vénète VIII: Les “tablettes alphabétiques” d’Este, technique orthographique et magie', Revue de Philol

ogie 26, 199-204.

Lejeune, M. 1971: 'Sur l'enseignement de l'écriture et de l'orthographe vénètes à Este', Bulletin de la Société de Linguistique de Paris 66, 267-98.

Lejeune, M. 1974: Manuel de la langue vénète, Heidelberg.

Lomas, K. 2008: 'Script obsolescence in Ancient Italy: from pre-Roman to Roman writing', in J. Baines, J. Bennet, and S. Houston (eds), The Disappearance of Writing Systems: Perspectives on Literacy and Communication, London, 109-38.

Lomas, K. 2009: 'Gender identities and cultural identities in the pre-Roman Veneto', in E. Herring and K. Lomas (eds), Gender Identities in Italy in the First Millennium BC, Oxford, $13-26$.

Maggiani, A. 2002: 'Luoghi di culto e divinità a Este', in A. Ruta Serafini (ed.), Este preromana: una città e i suoi santuari, Treviso, 77-88.

Maras, D. F. 2012: 'Interferenza e concorrenza di modelli alfabetici e sistemi scrittori nell'Etruria arcaica', Mélanges de l'École française de Rome - Antiquité 124, 331-44.

Maras, D. F. 2015: 'Etruscan and Italic literacy and the case of Rome', in W. M. Bloomer (ed.), $A$ Companion to Ancient Education, Chichester, 201-25.

Marinetti, A. 1990: 'Le tavolette alfabetiche di Este', in Pandolfini and Prosdocimi 1990, 95142. 
Marinetti, A. 1998: 'Il venetico. Bilancio e prospettive', in A. Marinetti, M. T. Vigolo, and A. Zamboni (eds), Varietà e continuità nella storia linguistica del Veneto. Atti del convegno della Società italiana di glottologia, Padova-Venezia, 3-5 ottobre 1996, Padua, 49-99.

Marinetti, A. 1999: 'Venetico 1976-1996. Acquisizioni e prospettive', in O. Paoletti (ed.), Protostoria e storia del 'Venetorum Angulus'. Atti del XX convegno di studi etruschi ed italici, Pisa and Rome, 391-436.

Marinetti, A. 2004: 'Venetico: Rassegna di nuove iscrizioni (Este, Altino, Auronzo, S. Vito, Asolo)', Studi Etruschi 70, 389-408.

McDonald, K. 2015: Oscan in Southern Italy and Sicily: Evaluating Language Contact in a Fragmentary Corpus, Cambridge.

McDonald, K. forthcoming: 'The dedications to Reitia and the epigraphic visibility of women in Este and the Veneto', in E. Dupraz and M. J. Estarán Tolosa (eds), Parole per gli dèi. Dediche religiose in lingue epicoriche del Mediterraneo Occidentale, Geneva.

Milnor, K. 2014: Graffiti and the Literary Landscape in Roman Pompeii, Oxford and New York. Morgan, T. 1998: Literate Education in the Hellenistic and Roman Worlds, Cambridge.

Pandolfini, M. and Prosdocimi, A. L. 1990: Alfabetari e insegnamento della scrittura in Etruria e nell'Italia antica, Florence.

Pascucci, P. 1990: I depositi votivi paleoveneti. Per un'archeologia del culto, Padua.

Pellegrini, G. B. and Prosdocimi, A. L. 1967: La lingua venetica, 2 vols, Padua.

Perego, E. 2010: 'Magic and ritual in Iron Age Veneto, Italy', Papers from the Institute of Archaeology 20, 67-96.

Prosdocimi, A. L. 1983: 'Puntuazione sillabica e insegnamento della scrittura nel venetico e nelle fonti etrusche', AION. Annali dell'Istituto universitario orientale di Napoli, Sezione linguistica $5,75-126$.

Prosdocimi, A. L. 1990: 'Insegnamento e apprendimento della scrittura nell'Italia antica', in Pandolfini and Prosdocimi 1992, 157-298.

Rix, H. 1960: 'Zu den venetischen Schrifttäfelchen', Indogermanische Forschungen 65, 124-39.

Roth, U. 2011: 'Textile production and gender in ancient Italy: the case of the "Oscan" loom weights', Ostraka 20, 143-62.

Rüpke, J. 2009: 'Dedications accompanied by inscriptions in the Roman Empire: functions, intentions, modes of communication', in J. Bodel and M. Kajava (eds), Dediche sacre nel mondo greco-romano. Diffusione, funzioni, tipologie, Rome, 31-41.

Snodgrass, A. 1989: 'The economics of dedication at Greek sanctuaries', in G. Bartoloni, G. Colonna, C. Gotanelli and A. Vivante (eds), Atti del convegno internazionale 'Anathema'. 
Regime delle offerte e vita dei santuari nel mediterraneo antico', Roma, 15-18 giugno 1989, Rome, 287-94.

Stoddart, S. and Whitley, J. 1988: 'The social context of literacy in Archaic Greece and Etruria', Antiquity 62, 761-72.

Tomlin, R. S. O. 2002: 'Writing to the gods in Britain', in A. Cooley (ed.), Becoming Roman, Writing Latin? Literacy and Epigraphy in the Roman West, Journal of Roman Archaeology Supplementary Series 48, Portsmouth, RI, 165-79.

G. Tosi (ed.) 1992: Este antica. Dalla preistoria all'età romana, Este.

Turfa, J. M. 2006: 'Votive offerings in Etruscan religion', in N. Thomson de Grummond and E. Simon (eds), The Religion of the Etruscans, Austin, 90-115.

Várhelyi, Z. 1996: 'The written word in Archaic Attica', Klio 78, 28-52.

Wachter, R. 1986: 'Die etruskische und venetische Silbenpunktierung', Museum Helveticum 43, 111-26.

Wallace, R. 2008: Zikh Rasna: A Manual of the Etruscan Language and Inscriptions, Ann Arbor.

West, W. C., 2015: 'Learning the alphabet: abecedaria and the early schools in Greece', Greek, Roman and Byzantine Studies 55, 52-71.

Whatmough, J. 1922: 'Rehtia, the Venetic goddess of healing', Journal of the Royal Anthropological Institute of Great Britain and Ireland 52, 212-29.

Woodard, R. D. 2014: The Textualization of the Greek Alphabet, Cambridge.

Zavaroni, A. 2008: 'Sulla presunta equivalenza fra venetico “op voltio leno" e lat. "libens merito"', Latomus 67, 619-26. 